\title{
Application and performance of Kestrel sensors for assessing thermal comfort in outdoor built environments
}

\author{
Author(s) \\ Klok, Lisette; Caverzam Barbosa, Erica; van Zandbrink, Luc; Kluck, Jeroen \\ DOI
}

10.5194/egusphere-egu21-13237

Publication date

2021

Document Version

Final published version

License

CC BY

Link to publication

Citation for published version (APA):

Klok, L., Caverzam Barbosa, E., van Zandbrink, L., \& Kluck, J. (2021). Application and performance of Kestrel sensors for assessing thermal comfort in outdoor built environments.

https://doi.org/10.5194/egusphere-egu21-13237

It is not permitted to download or to forward/distribute the text or part of it without the consent of the author(s) and/or copyright holder(s), other than for strictly personal, individual use, unless the work is under an open content license (like Creative Commons).

\section{Disclaimer/Complaints regulations}

If you believe that digital publication of certain material infringes any of your rights or (privacy) interests

please let the Library know, stating your reasons. In case of a legitimate complaint, the Library will make the material inaccessible and/or remove it from the website. Please contact the library:

https://www.amsterdamuas.com/library/contact/questions, or send a letter to: University Library (Library of the University of Amsterdam and Amsterdam University of Applied Sciences), Secretariat, Singel 425, 1012 WP Amsterdam, The Netherlands. You will be contacted as soon as possible. 


\section{\3ogeschool van Amsterdam}
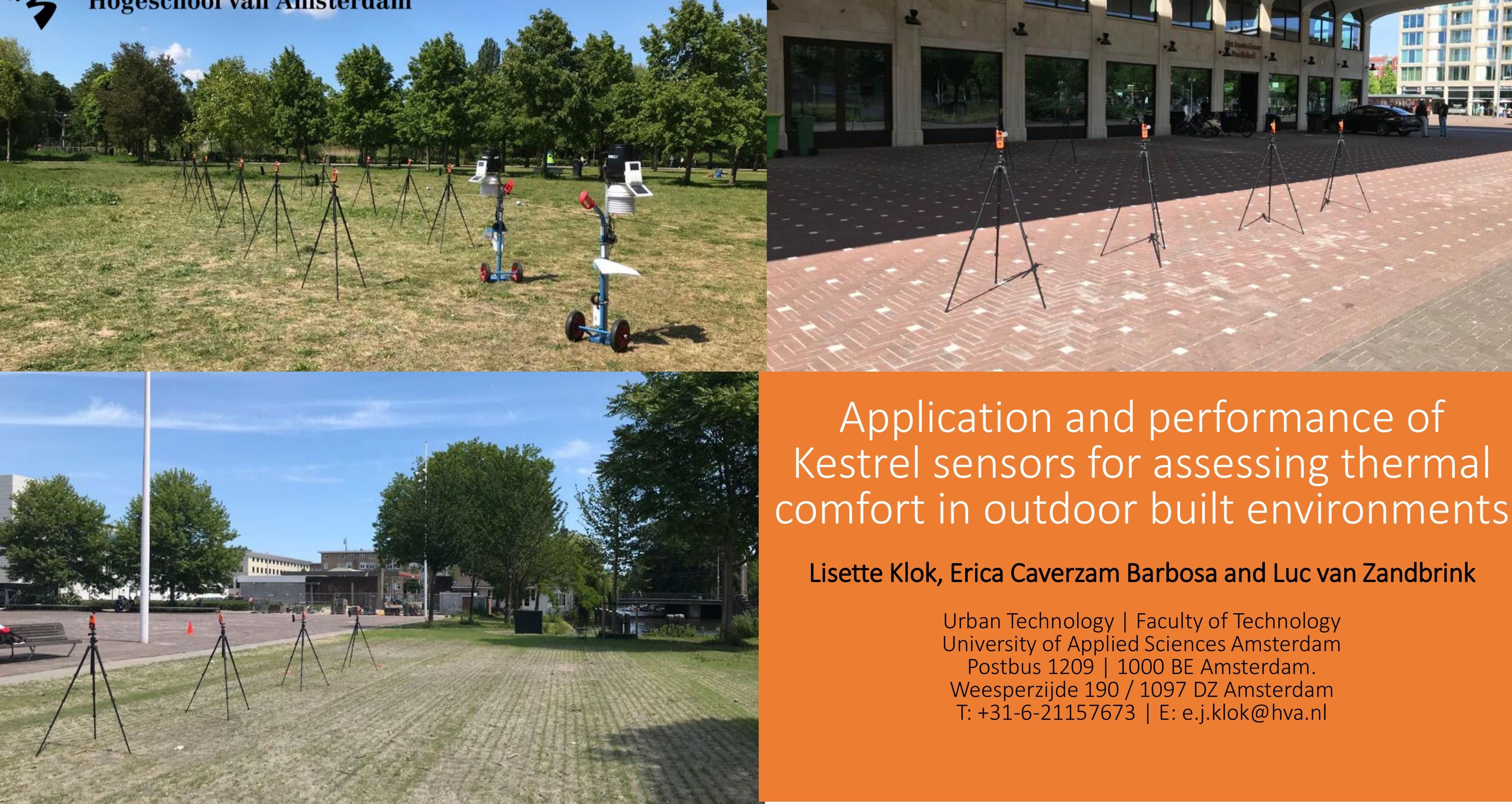

\section{Application and performance of}

Kestrel sensors for assessing thermal comfort in outdoor built environments

\section{Lisette Klok, Erica Caverzam Barbosa and Luc van Zandbrink}

Urban Technology | Faculty of Technology

University of Applied Sciences Amsterdam

Postbus 1209 | 1000 BE Amsterdam.

Weesperzijde 190 / 1097 DZ Amsterdam

T: +31-6-21157673 | E: e.j.klok@hva.nl 


\section{INTRODUCTION}

In face of climate change and urbanization, the need for thermally comfortable outdoor urban spaces is increasing. In the design of the thermally comfortable urban spaces and decision making about interventions that enhance thermal comfort, scientists and professionals that work for cities use meteorological measurements and models. These measurements can be done by professional and accurate meteorological sensors, but also by simpler mobile instruments such as the easy-touse Kestrel weather meters. In using these simple type of sensors, it is important to know what the performance of these sensors is for outdoor thermal comfort assessments and how they can be used by scientists and professionals in decision making about urban designs that enhance thermal comfort.

To answer these questions, we carried out three experiments in the summer of 2020 in Amsterdam, the Netherlands, in which we tested the 11 Kestrel 5400 heat stress sensors and assessed the performance of this equipment for thermal comfort studies. 


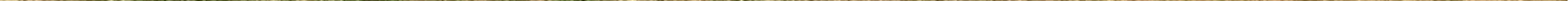




\section{Location: Park Frankendael}

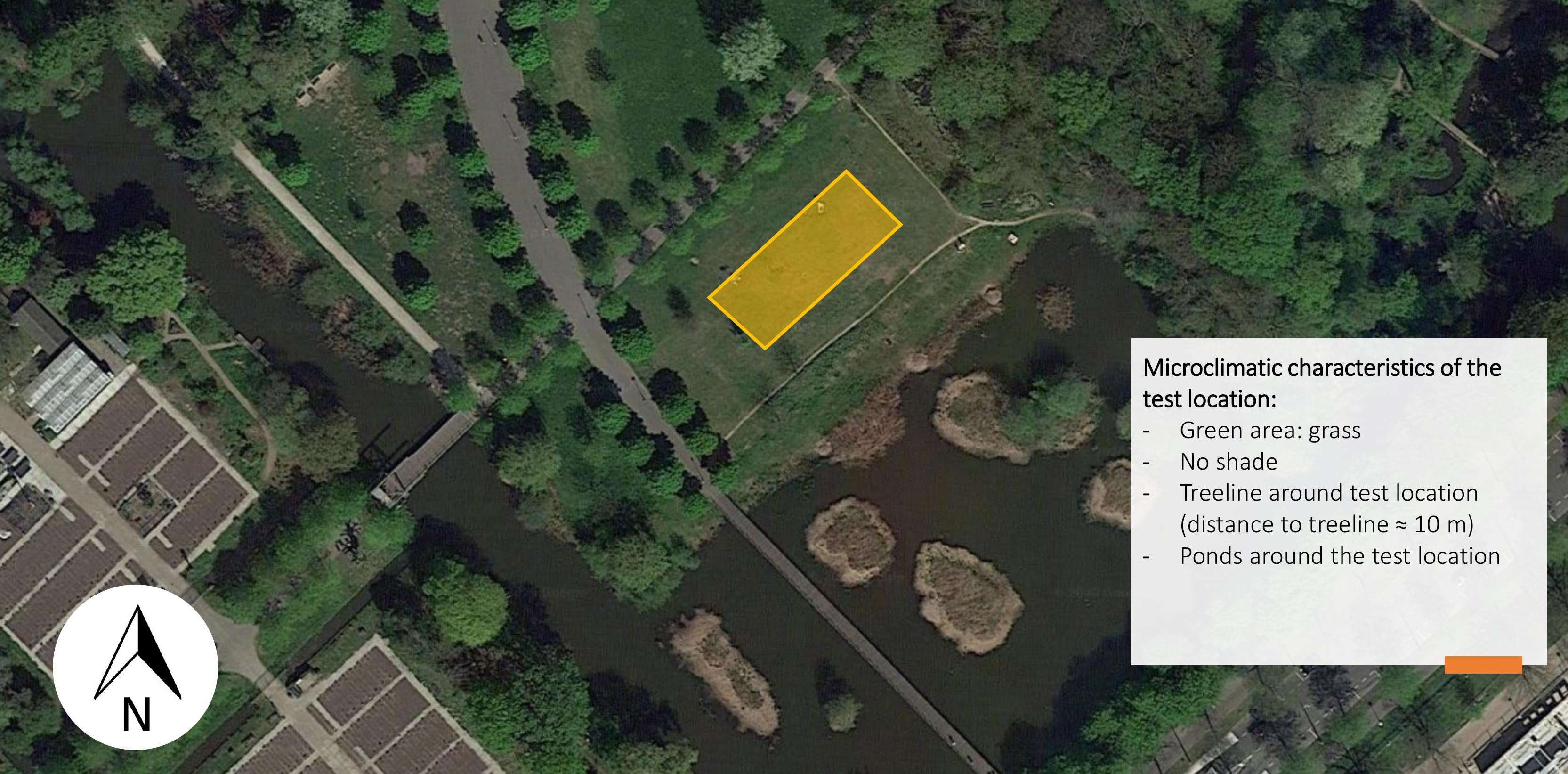




\section{Dutch weather report}

\section{Daggegevens van het weer in Nederland}

Het weer op dinsdag 19 mei 2020 te Schiphol

\section{Temperatuur}

Gemiddelde

Maximum

Minimum

$15.5^{\circ} \mathrm{C}$

$20.2^{\circ} \mathrm{C}$

$10.3^{\circ} \mathrm{C}$

\section{Zon, bewolking \& zicht}

Duur zonneschijn

Rel. zonneschijnduur

Gem. bedekkingsgraad

Minimaal zicht

Relatieve luchtvochtigheid

Gemiddelde

$\begin{aligned} 11.7 & \text { uur } \\ 74 & \% \\ 5 & \text { octa's }\end{aligned}$

Half tot zwaar bewolkt

$9.0 \mathrm{~km}$
$75 \%$

\section{Normaal Neerslag}

$13.2^{\circ} \mathrm{C}$

$17.8^{\circ} \mathrm{C}$

$8.4^{\circ} \mathrm{C}$

\section{Wind}

Gemiddelde snelheid

$47 \%$

Maximale uurgemiddelde snelheid

Maximale stoot

Overheersende richting

\section{Luchtdruk}

$0.0 \mathrm{~mm}$

0.0 uur

$3.5 \mathrm{~m} / \mathrm{s}$

$7.0 \mathrm{~m} / \mathrm{s}$

(3 $\mathrm{Bft})$

(4 Bft)

$10.0 \mathrm{~m} / \mathrm{s}$

$282^{\circ}$

(W) 


\section{Set up:}

Start time: $11: 46 \mathrm{~h}$ End time: 16:00 h

Time interval measurements: 1 minute

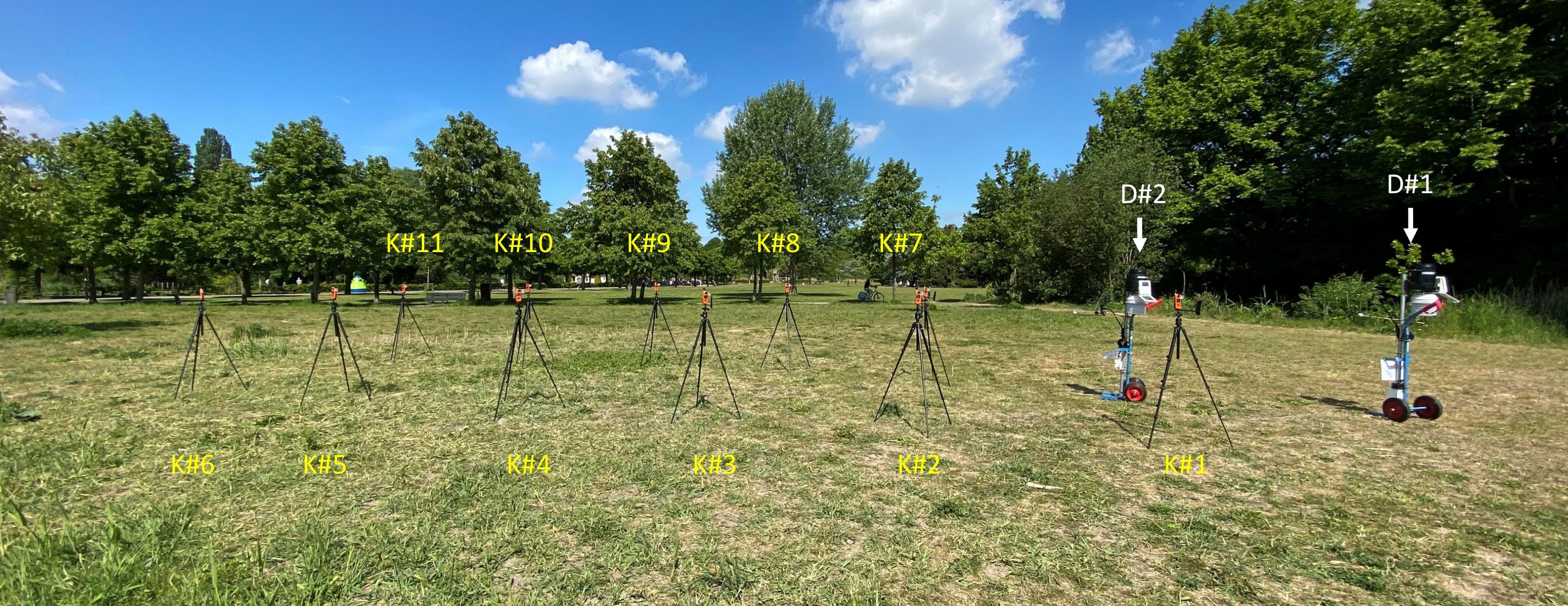




\section{Parameters}

- Air temperature

- Humidity

- Wind speed

- Globe temperature

- Mean Radiant Temperature

Thorsson et al. (2007):

$$
T_{m r t}=\left[\left(T_{g}+273.15\right)^{4}+\frac{1.1 \times 10^{8} V_{a}^{0.6}}{\left(D^{2.4}\right.} \times\left(T_{g}-T_{a}\right)\right]^{\frac{1}{4}}-273.15
$$

Walikewitz et al. (2015):

Black globe (Kestrel): $1.1 \times 10^{8} V_{a}^{0.6}$

Grey globe (Davis): $1.335 \times 10^{8} V_{a}^{0.71}$

$$
\begin{aligned}
& \text { RMSE }=\sqrt{\frac{\sum_{i=1}^{n}\left(x_{1, i}-x_{2, i}\right)^{2}}{n}} \\
& \text { Ref }=\text { average Kestrels }
\end{aligned}
$$

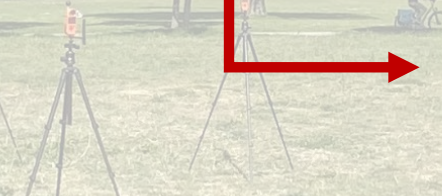

Davis $=38 \mathrm{~mm} \quad$ Kestrel $=150$ $\mathrm{mm}$

- PET is calculated with Raymann v. 1.2 based om 10-min averages of air temperature, globe temperature, wind speed and TMRT (10 min)

- According to the website of Kestrel, the temperature inside a 1-inch black powder-coated copper globe is converted to $\mathrm{Tg}$ equivalent for a standard 6 inches $(150 \mathrm{~mm})$ globe. 


\section{Results - Air temperature}

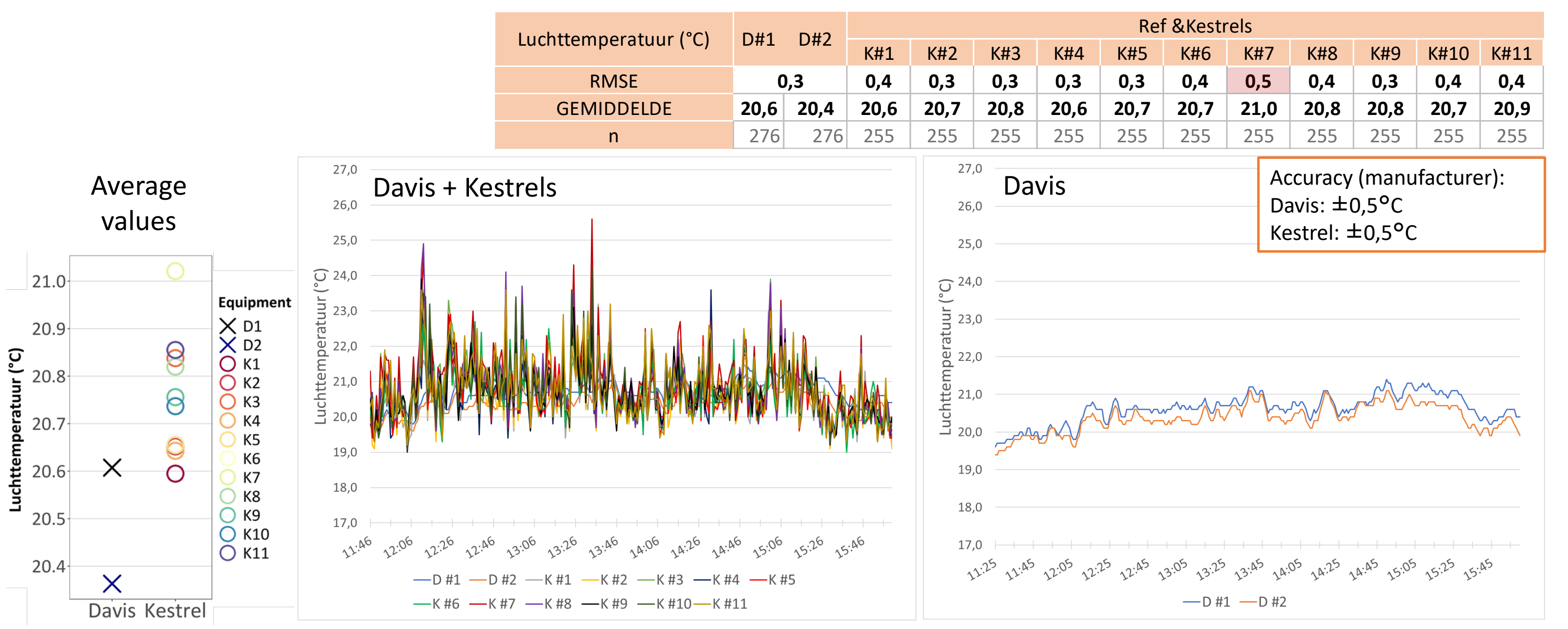




\section{Results - Air temperature - 10 min running average}
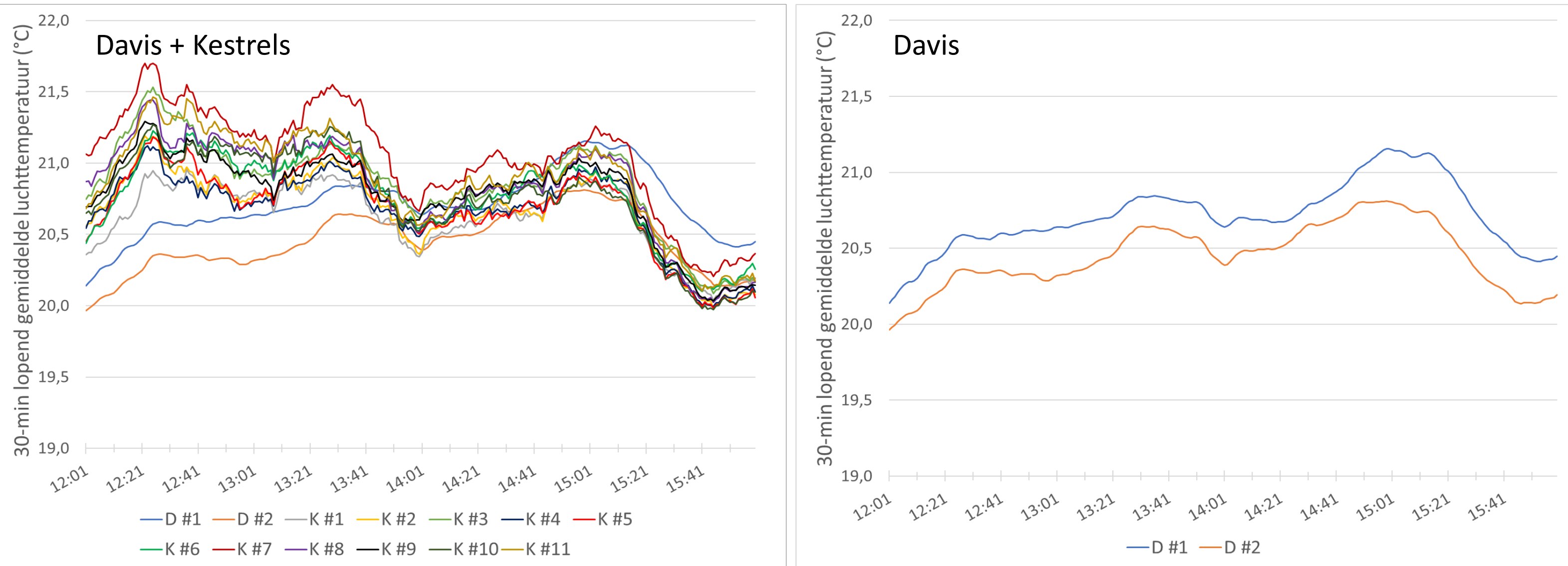


\section{Results - Humidity}

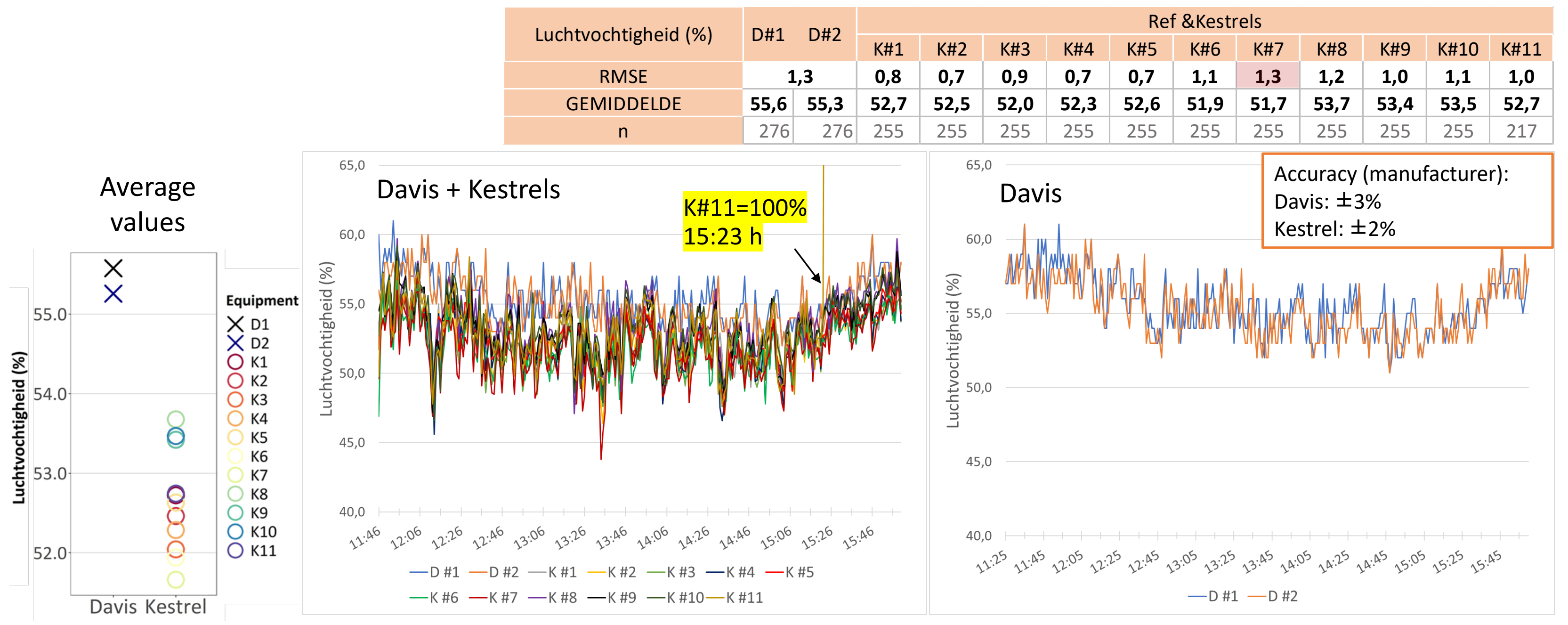




\section{Results - Wind speed}

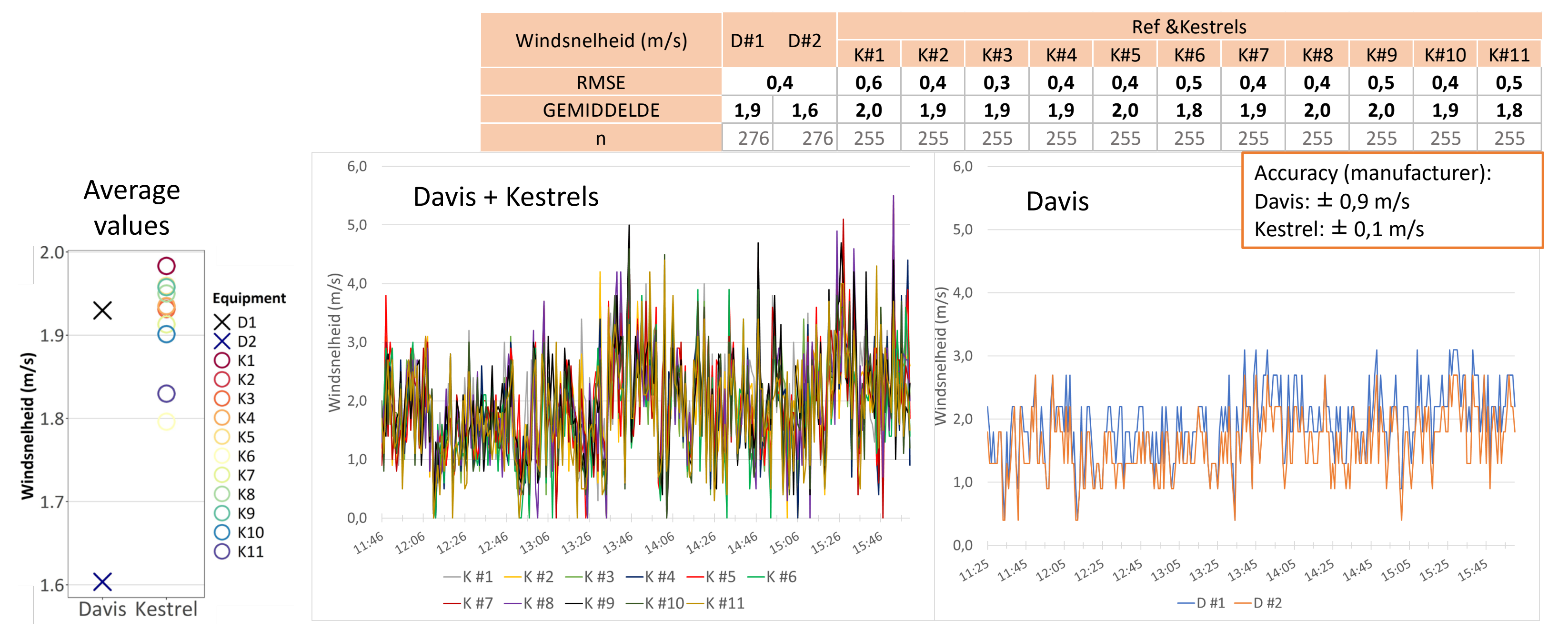




\section{Results - Wind speed-30 min running average}
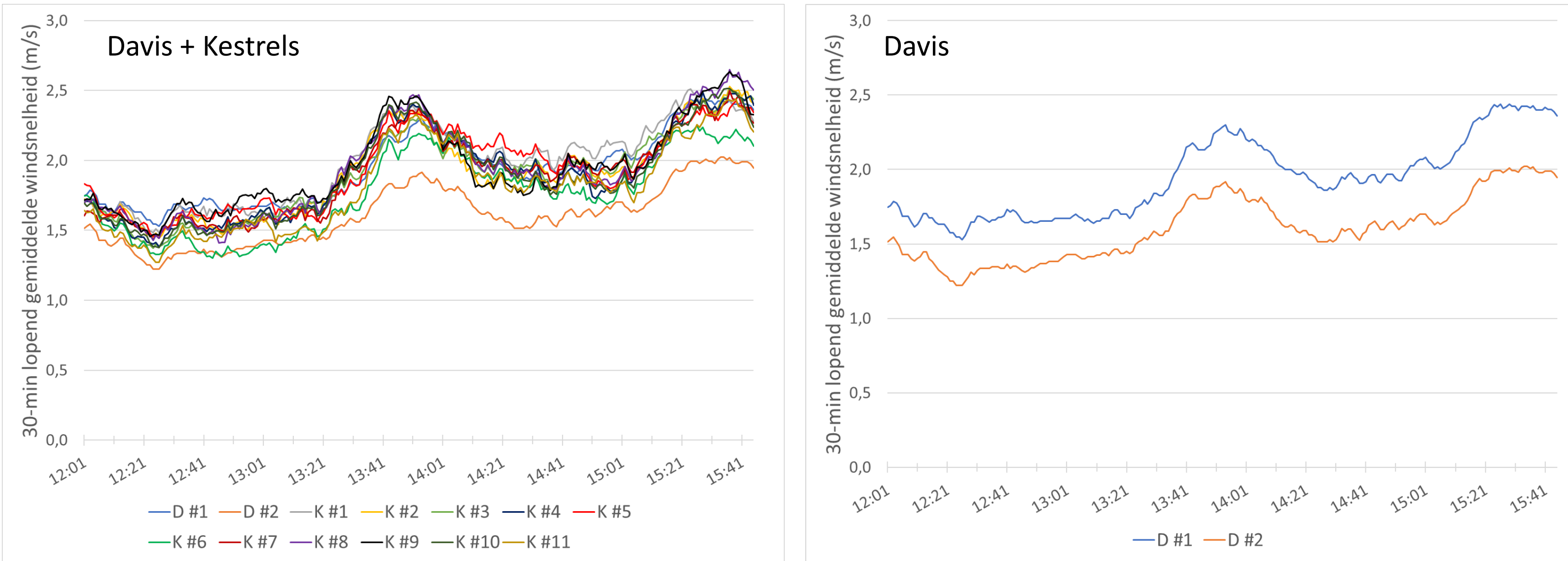


\section{Results - Globe temperature}

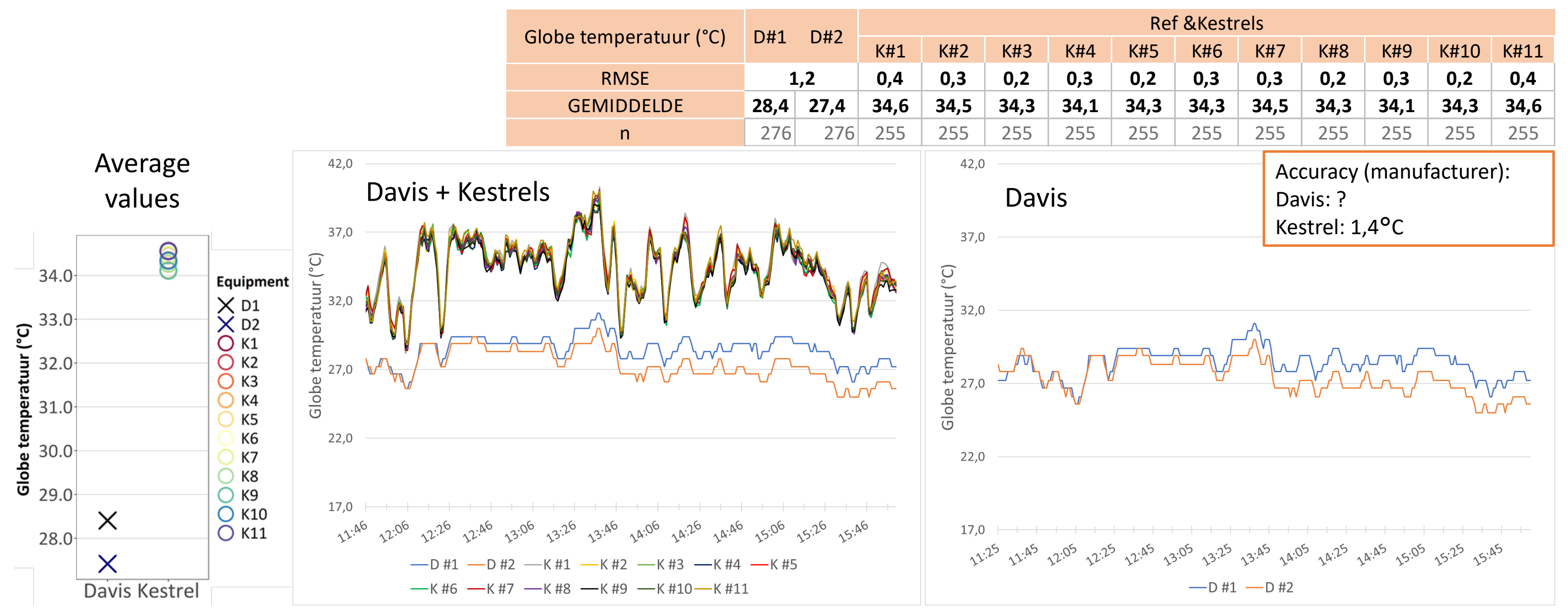




\section{Results - Mean Radiant Temperature}

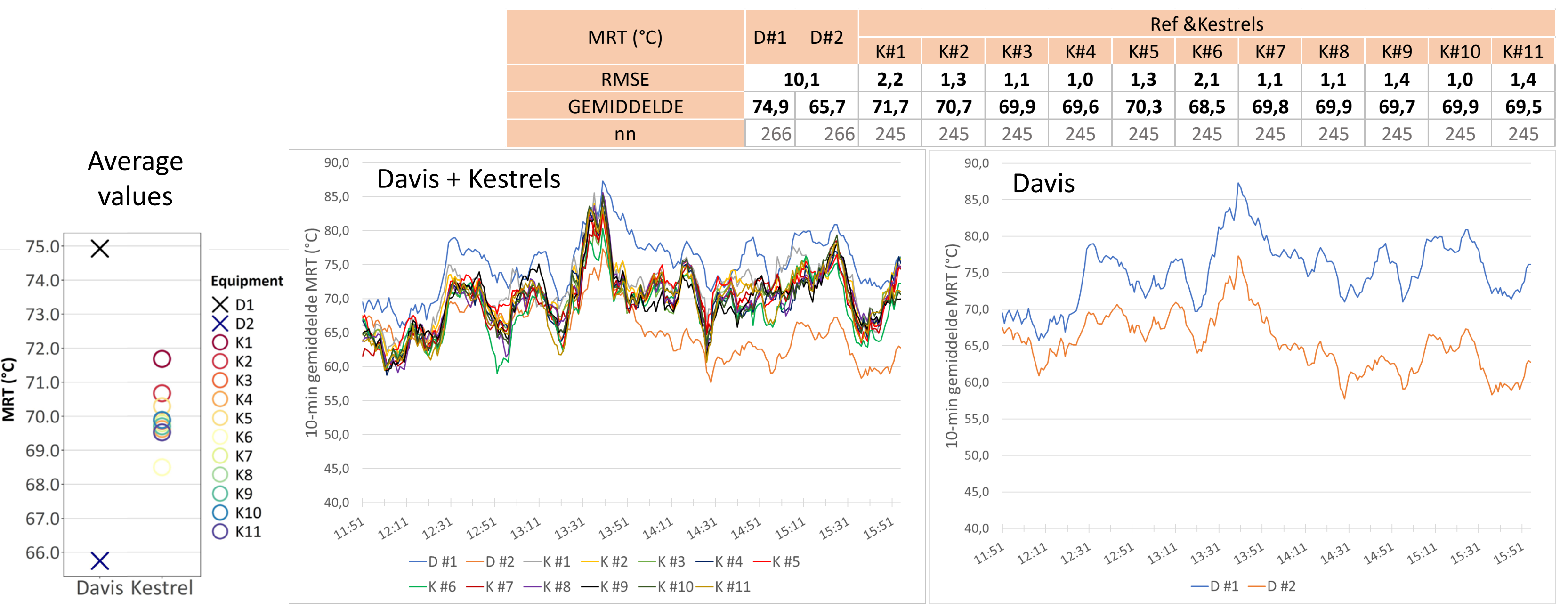




\section{Results - PET (10-min average)}

\begin{tabular}{|c|c|c|c|c|c|c|c|c|c|c|c|c|c|}
\hline \multirow{2}{*}{$\operatorname{PET}\left({ }^{\circ} \mathrm{C}\right)$} & \multirow{2}{*}{ D\#1 } & \multirow{2}{*}{ D\#2 } & \multicolumn{11}{|c|}{ Ref \&Kestrels } \\
\hline & & & K\#1 & K\#2 & K\#3 & K\#4 & K\#5 & K\#6 & K\#7 & K\#8 & K\#9 & K\#10 & K\#11 \\
\hline RMSE & \multicolumn{2}{|c|}{3,9} & 0,5 & 0,3 & 0,2 & 0,4 & 0,3 & 0,4 & 0,3 & 0,3 & 0,4 & 0,3 & 0,4 \\
\hline GEMIDDELDE & 38,4 & 35,0 & 36,5 & 36,4 & 36,1 & 35,9 & 36,1 & 36,0 & 36,3 & 36,1 & 35,9 & 36,2 & 36,8 \\
\hline$n$ & 256 & 256 & 235 & 235 & 235 & 235 & 235 & 235 & 235 & 235 & 235 & 235 & 202 \\
\hline
\end{tabular}
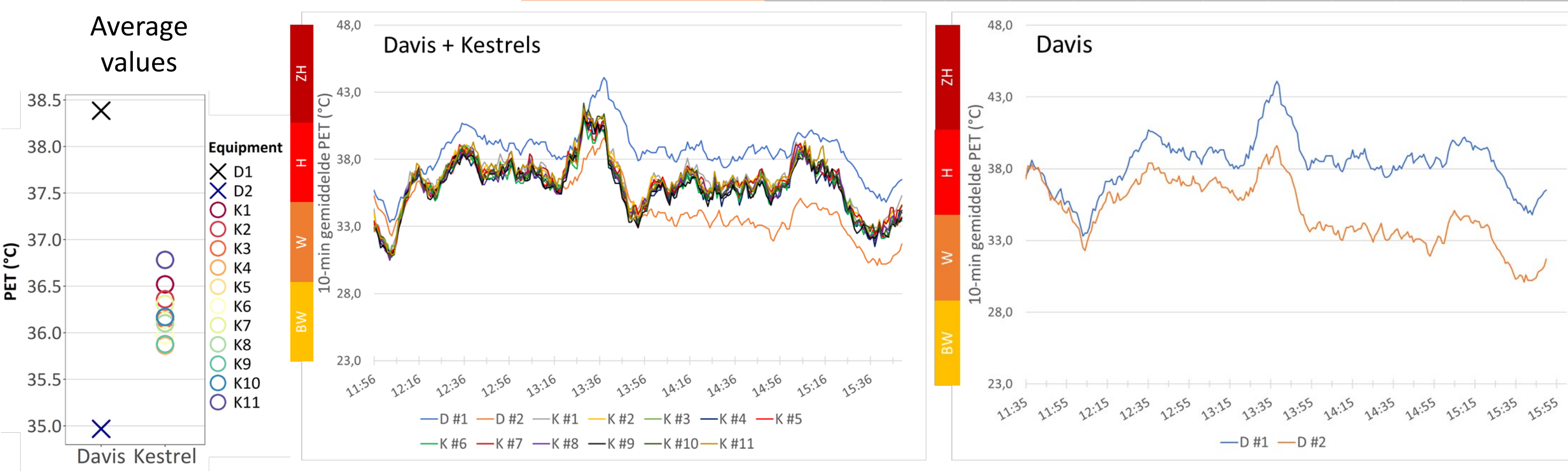

PET classification: Very Hot (>41 C), Hot (41-35 C), Warm (35-29 C), Slightly warm (29-23 C), Comfortable (23-18 C), Slightly Cool (18-13 C), Cool (13-8 C), Cold (8-4 C), Extremely Cold (<4 C). (Coccolo et al., 2016). 


\section{Results - sensitivity of MRT-calculation with respect to air temperature}

$$
25,0
$$

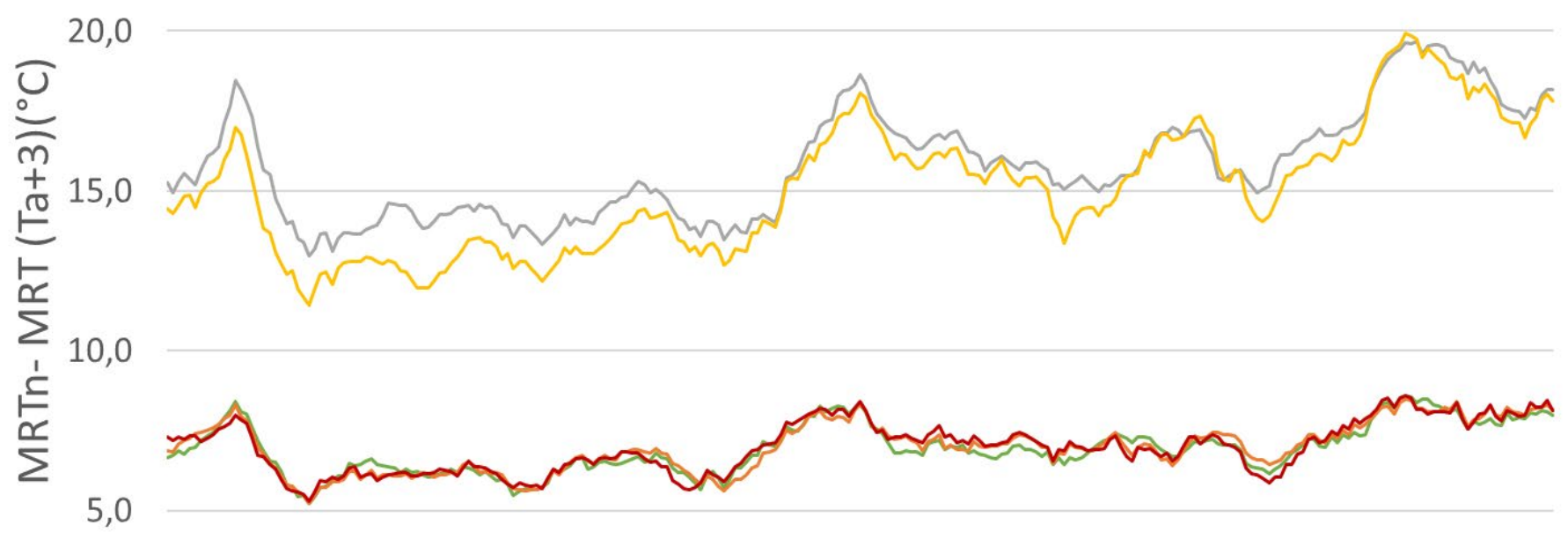

$$
\begin{aligned}
& 0,0
\end{aligned}
$$

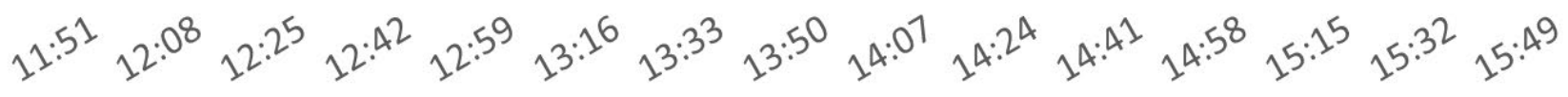

$$
\begin{aligned}
& \text {-D\#1 -D\#2 -K\#2-K\#3-K\#4 }
\end{aligned}
$$

- D\#1, D\#2, K\#2, K\#3, and K\#4 were selected for a sensitivity analysis with respect to air temperature.

- Air temperatures of these sensors were increased by $3^{\circ} \mathrm{C}$. The other variables were kept the same.

- MRTn -> normal MRT (see previous slides).

- $\operatorname{MRT}(\mathrm{Ta}+3)$-> MRT calculated with an increase of $3^{\circ} \mathrm{C}$ for the air temperature.

- Result: The MRT calculation of the Davis is more sensitive for a difference in air temperature than the Kestrel. A higher air temperature leads to lower MRT, which is a consequence of the equation (Thorsson et al., 2007)). 


\section{Results - sensitivity of PET-calculation with respect to air temperature}

6,0

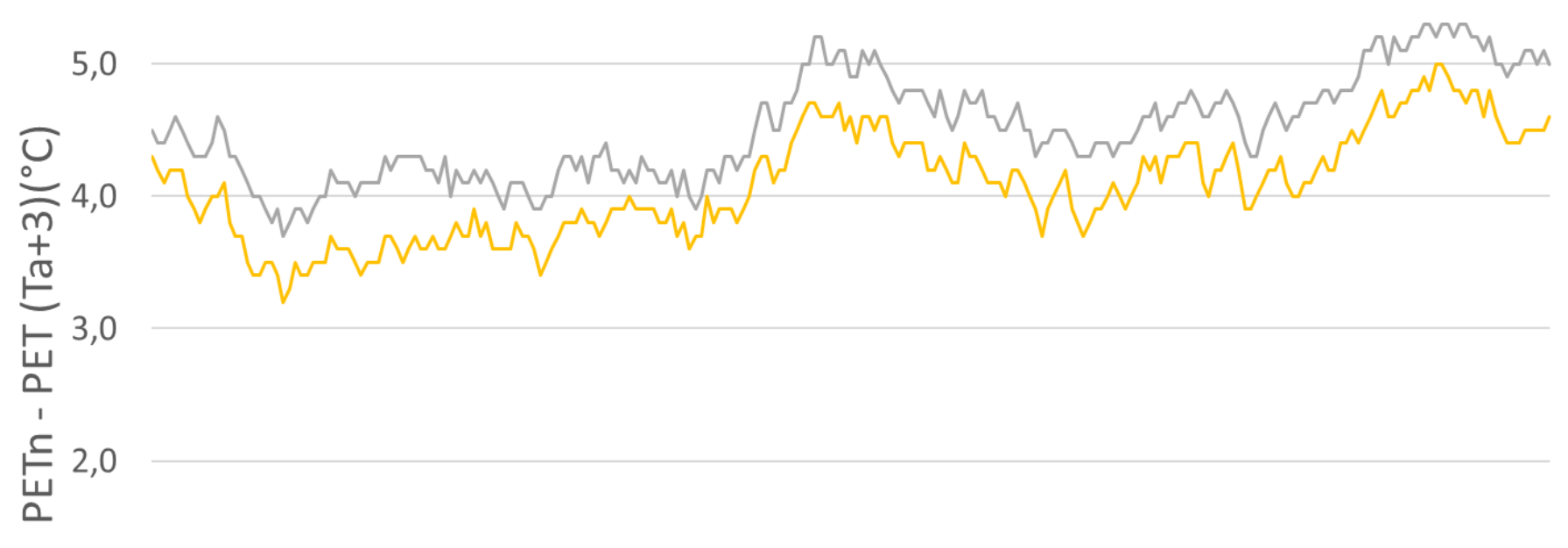

1,0

$$
0,0
$$

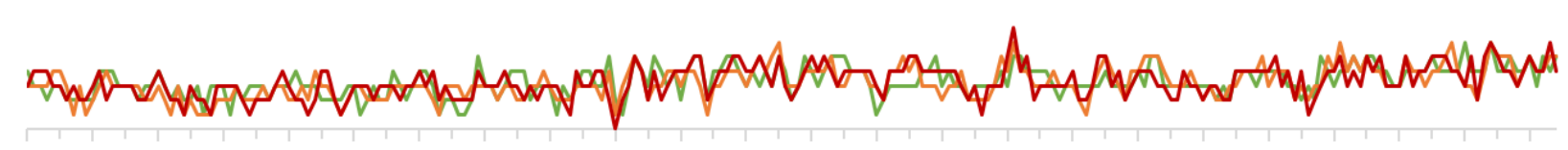

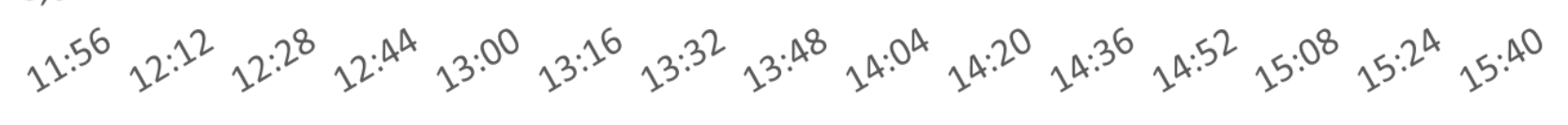

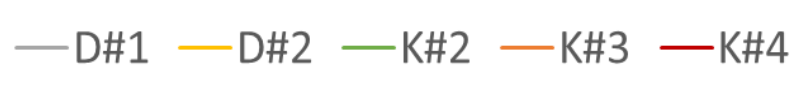

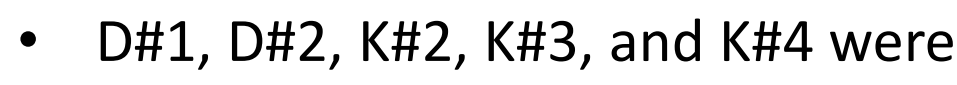
selected for a sensitivity analysis with respect to air temperature.

- Air temperatures of these sensors were increased by $3^{\circ} \mathrm{C}$. The other variables were kept the same.

- PETn -> normal PET (previous slides).

- $\operatorname{PET}(\mathrm{Ta}+3)->$ PET calculated with an increase of $3^{\circ} \mathrm{C}$ for the air temperature.

- Result: Differences in air temperature almost have no effect on the PETcalculation of the Kestrels, but it does for the Davis. 


\section{Results - overview}

\begin{tabular}{|c|c|c|c|c|c|c|c|c|c|c|c|c|}
\hline \multirow{2}{*}{ RMSE - 2020} & \multirow{2}{*}{ Davis } & \multicolumn{11}{|c|}{ Ref \&Kestrels } \\
\hline & & K\#1 & K\#2 & K\#3 & K\#4 & K\#5 & K\#6 & K\#7 & K\#8 & K\#9 & K\#10 & K\#11 \\
\hline Luchttemperatuur $\left({ }^{\circ} \mathrm{C}\right)$ & 0,3 & 0,4 & 0,3 & 0,3 & 0,3 & 0,3 & 0,4 & 0,5 & 0,4 & 0,3 & 0,4 & 0,4 \\
\hline $\mathrm{n}$ & 276 & 255 & 255 & 255 & 255 & 255 & 255 & 255 & 255 & 255 & 255 & 255 \\
\hline Luchtvochtigheid (\%) & 1,3 & 0,8 & 0,7 & 0,9 & 0,7 & 0,7 & 1,1 & 1,3 & 1,2 & 1,0 & 1,1 & 1,0 \\
\hline $\mathrm{n}$ & 276 & 255 & 255 & 255 & 255 & 255 & 255 & 255 & 255 & 255 & 255 & 217 \\
\hline Windsnelheid $(\mathrm{m} / \mathrm{s})$ & 0,4 & 0,6 & 0,4 & 0,3 & 0,4 & 0,4 & 0,5 & 0,4 & 0,4 & 0,5 & 0,4 & 0,5 \\
\hline $\mathrm{n}$ & 276 & 255 & 255 & 255 & 255 & 255 & 255 & 255 & 255 & 255 & 255 & 255 \\
\hline Globe temperatuur $\left({ }^{\circ} \mathrm{C}\right)$ & 1,2 & 0,4 & 0,3 & 0,2 & 0,3 & 0,2 & 0,3 & 0,3 & 0,2 & 0,3 & 0,2 & 0,4 \\
\hline $\mathrm{n}$ & 276 & 255 & 255 & 255 & 255 & 255 & 255 & 255 & 255 & 255 & 255 & 255 \\
\hline Zonnestraling $\left(\mathrm{W} / \mathrm{m}^{2}\right)$ & 135 & - & - & - & - & - & - & - & - & - & - & - \\
\hline $\mathrm{n}$ & 276 & - & - & - & - & - & - & - & - & - & - & - \\
\hline $\operatorname{MRT}\left({ }^{\circ} \mathrm{C}\right)$ & 10,1 & 2,2 & 1,3 & 1,1 & 1,0 & 1,3 & 2,1 & 1,1 & 1,1 & 1,4 & 1,0 & 1,4 \\
\hline $\mathrm{n}$ & 266 & 245 & 245 & 245 & 245 & 245 & 245 & 245 & 245 & 245 & 245 & 245 \\
\hline $\operatorname{PET}\left({ }^{\circ} \mathrm{C}\right)$ & 3,9 & 0,5 & 0,3 & 0,2 & 0,4 & 0,3 & 0,4 & 0,3 & 0,3 & 0,4 & 0,3 & 0,4 \\
\hline $\mathrm{n}$ & 256 & 235 & 235 & 235 & 235 & 235 & 235 & 235 & 235 & 235 & 235 & 202 \\
\hline
\end{tabular}




\section{Comparing RMSE with experiments carried out in 2019 and accuracy given by manufacturer and}

\begin{tabular}{|c|c|c|c|c|c|c|c|}
\hline \multirow[t]{2}{*}{ RMSE - $2019 \& 2020$} & \multicolumn{3}{|c|}{2019} & \multicolumn{2}{|c|}{2020} & \multicolumn{2}{|c|}{$\begin{array}{c}\text { Nauwkeurigheid } \\
\text { (fabrikant) }\end{array}$} \\
\hline & Davis $\times$ Davis & 2 Davis $\times 2$ Kestrels & 2 Kestrels & DavisxDavis & 11 Kestrels & Davis & Kestrel \\
\hline Luchttemperatuur $\left({ }^{\circ} \mathrm{C}\right)$ & 0,3 & $0,6-0,7$ & 0,2 & 0,3 & $0,3-0,5$ & 0.5 & 0.5 \\
\hline $\mathrm{N}$ & 865 & 215 & 215 & 276 & 255 & 0,0 & $0, כ$ \\
\hline Luchtvochtigheid (\%) & 0,7 & $3,9-4,2$ & 0,2 & 1,3 & $0,7-1,3$ & 20 & 30 \\
\hline $\mathrm{N}$ & 865 & 215 & 215 & 276 & $255^{*}$ & 2,0 & 3,0 \\
\hline Windsnelheid $(\mathrm{m} / \mathrm{s})$ & 0,6 & 0,8 & 0,4 & 0,4 & $0,3-0,6$ & 00 & 01 \\
\hline $\mathrm{N}$ & 865 & 215 & 215 & 276 & 255 & , & 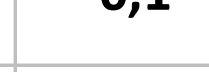 \\
\hline Globe temperatuur $\left({ }^{\circ} \mathrm{C}\right)$ & 0,4 & - & 0,3 & 1,2 & $0,2-0,4$ & $?$ & 14 \\
\hline $\mathrm{N}$ & 671 & - & 215 & 276 & 255 & & \\
\hline Zonnestraling $\left(\mathrm{W} / \mathrm{m}^{2}\right)$ & 88 & - & - & 135 & - & 50 & - \\
\hline $\mathrm{N}$ & 865 & - & - & 276 & - & & \\
\hline $\operatorname{MRT}\left({ }^{\circ} \mathrm{C}\right)$ & 3,7 & $3,1-7,1$ & 1,6 & 10,1 & $1,0-2,2$ & & 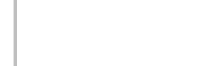 \\
\hline $\mathrm{N}$ & 671 & 149 & 215 & 266 & 245 & 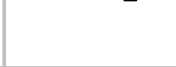 & - \\
\hline $\operatorname{PET}\left({ }^{\circ} \mathrm{C}\right)$ & 0,8 & $1,0-1,7$ & 0,6 & 3,9 & $0,2-0,5$ & 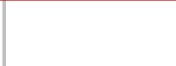 & 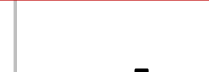 \\
\hline $\mathrm{N}$ & 671 & 149 & 215 & 256 & $235^{*}$ & 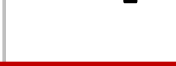 & \\
\hline
\end{tabular}




\section{Conclusions based on experiment 1}

- Air temperature:

- Kestrel and Davis sensors both deviate less than the accuracy specified by the manufacturer.

- However, the 1-minute time interval measurements of the Kestrel show large fluctuations. These might be caused by the increase in temperature of the Kestrel-casing (see next experiment). It is discouraged to use the Kestrel to determine the 1-minute temperature values.

- PET:

- Based on this research the Kestrels seem to determine the PET more accurate than the Davis. This might have been caused by problems with the wind sensor and the grey globe of the Davis. It is possible that the wind sensor of the Davis 2\# needs maintenance. The different grey balls of the globe temperature sensor of the Davis might explain the big differences in PET between the two Davis stations.

- The strong variation in measured Kestrel-temperatures has a low influence on the calculated PET-value, as is proven in a sensibility study. 


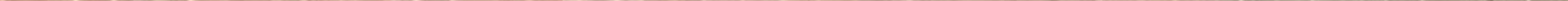




\section{Dutch wheater report}

\section{Daggegevens van het weer in Nederland} Het weer op dinsdag 26 mei 2020 te Schiphol

\section{Temperatuur}

Gemiddelde

Maximum

Minimum

\section{Zon, bewolking \& zicht}

Duur zonneschijn

Rel. zonneschijnduur

Gem. bedekkingsgraad

Minimaal zicht
Normaal

$13.7^{\circ} \mathrm{C}$

$18.1^{\circ} \mathrm{C}$

$9.0^{\circ} \mathrm{C}$

\section{Wind}

14.0 uur

$86 \%$

5 octa's

Half tot zwaar bewolkt

$10.0 \mathrm{~km}$

$45 \%$

\section{Relatieve luchtvochtigheid}

Gemiddelde

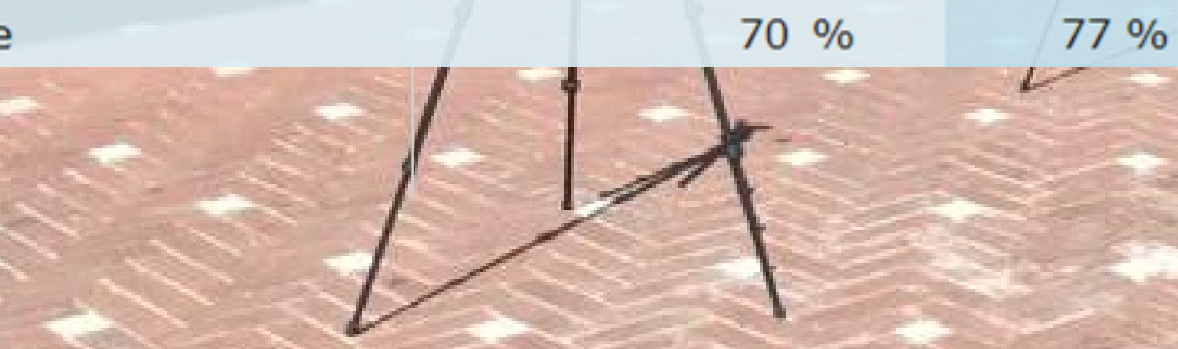

\section{Neerslag}

Hoeveelheid

Duur

$0.0 \mathrm{~mm}$

0.0 uur

Gemiddelde snelheid

Maximale uurgemiddelde snelheid

Maximale stoot

$2.6 \mathrm{~m} / \mathrm{s}$

$5.0 \mathrm{~m} / \mathrm{s}$

$7.0 \mathrm{~m} / \mathrm{s}$

Overheersende richting

$309 \circ$

(NW)

\section{Luchtdruk}

Gemiddelde luchtdruk

$1035.2 \mathrm{hPa}$
(2 Bft)

(3 Bft) 


\section{Results - Air temperature}

2nd experiment: Stadionplein

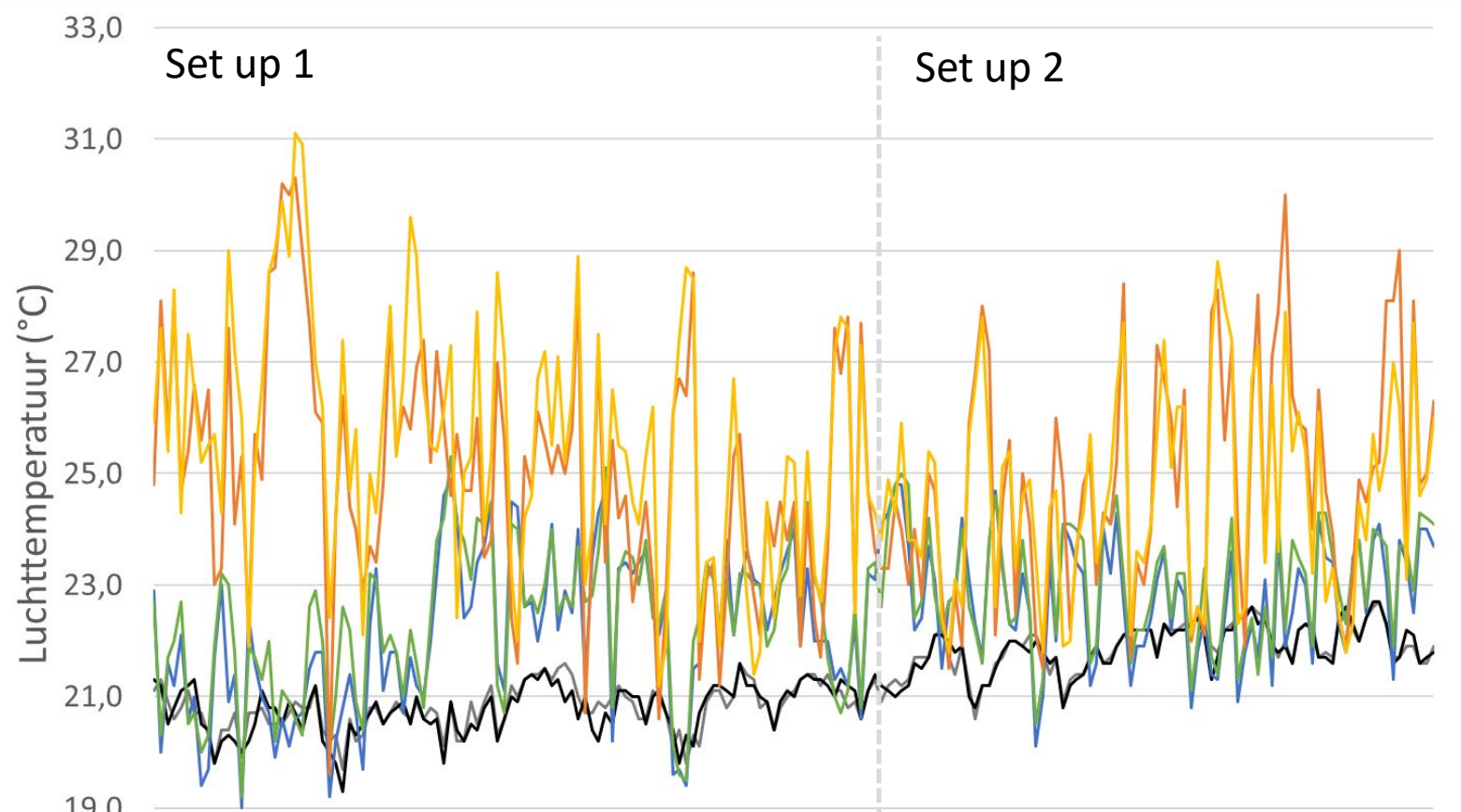

17,0

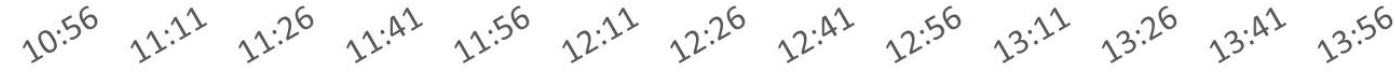

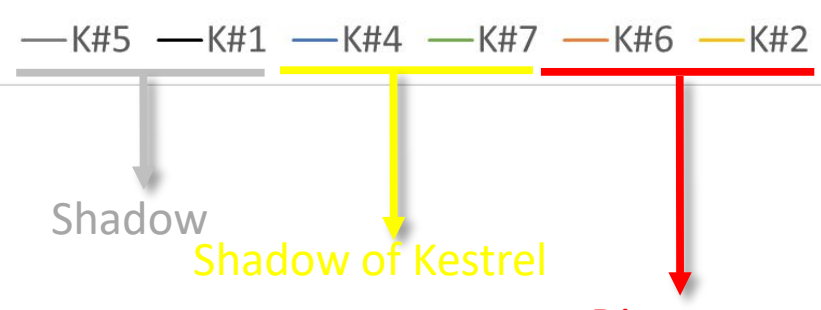

Period: 10:56-14:06 $\mathrm{h}$

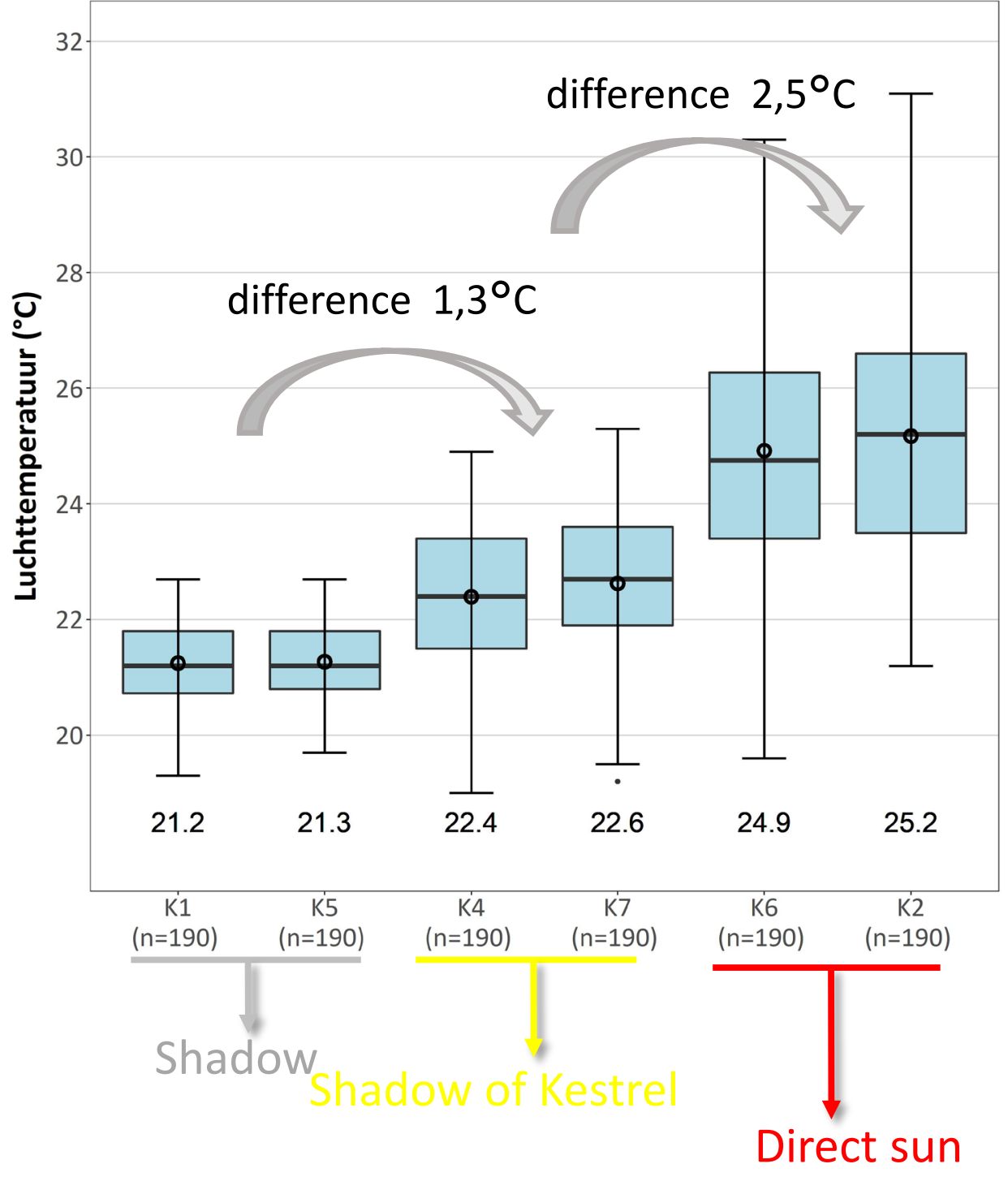




\section{Results - Air temperature}

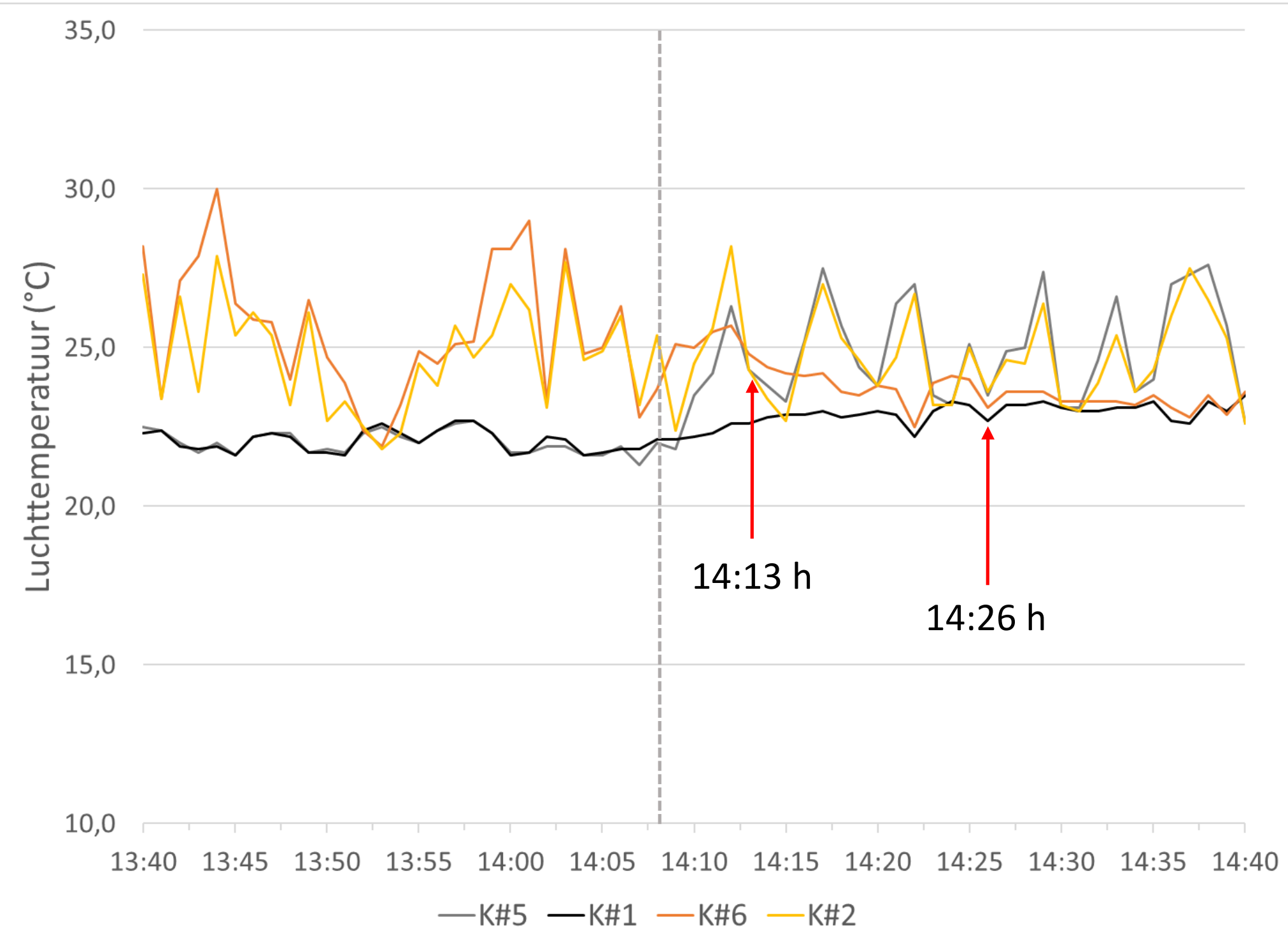

Time for stabilization:

- From shadow to sun: $5 \mathrm{~min}$ before the difference between $\mathrm{K} \# 5$ \& $\mathrm{K} \# 2$ becomes $<0,5^{\circ} \mathrm{C}$

- From sun to shadow: $20 \mathrm{~min}$ before the difference between $\mathrm{K} \# 6$ \& $\mathrm{K} \# 1$ becomes $0,5^{\circ} \mathrm{C}$ 


\section{Knowleage base}

\begin{tabular}{|l|}
\hline CATEGORY \\
\hline Manuals and Downloads \\
\hline $\begin{array}{l}\text { Kestrel LiNK Software and } \\
\text { Apps }\end{array}$ \\
\hline Kestrel 5 Series \\
\hline Kestrel Ballistics \\
\hline Kestrel 4 Series
\end{tabular}

\section{How do I get the most accurate measurements from my Kestrel?}

"All measurements not available in all units"

\section{Temperature Functions}

For best accuracy when taking temperature measurements you must keep the air moving around the temperature sensor and keep the Kestrel out of prolonged, direct sunlight. If there is a strong breeze, just point the Kestrel into the wind. If there is no wind, swing the Kestrel around in a circle on its lanyard or rapidly wave it back and forth in hand. This ensures that the sensor measures the temperature of the air rather than the temperature of the case. Alternatively, if you have time, allow the Kestrel to rest where you want to measure the air temperature (NOT in your hand or in direct sunlight if there is no wind) until the case temperature equalizes with the air temperature. When equalized, the display will read a constant value. Be aware that this could take a few minutes, particularly if there is no wind. 


\section{Results - Globe temperature}

2nd experiment: Stadionplein

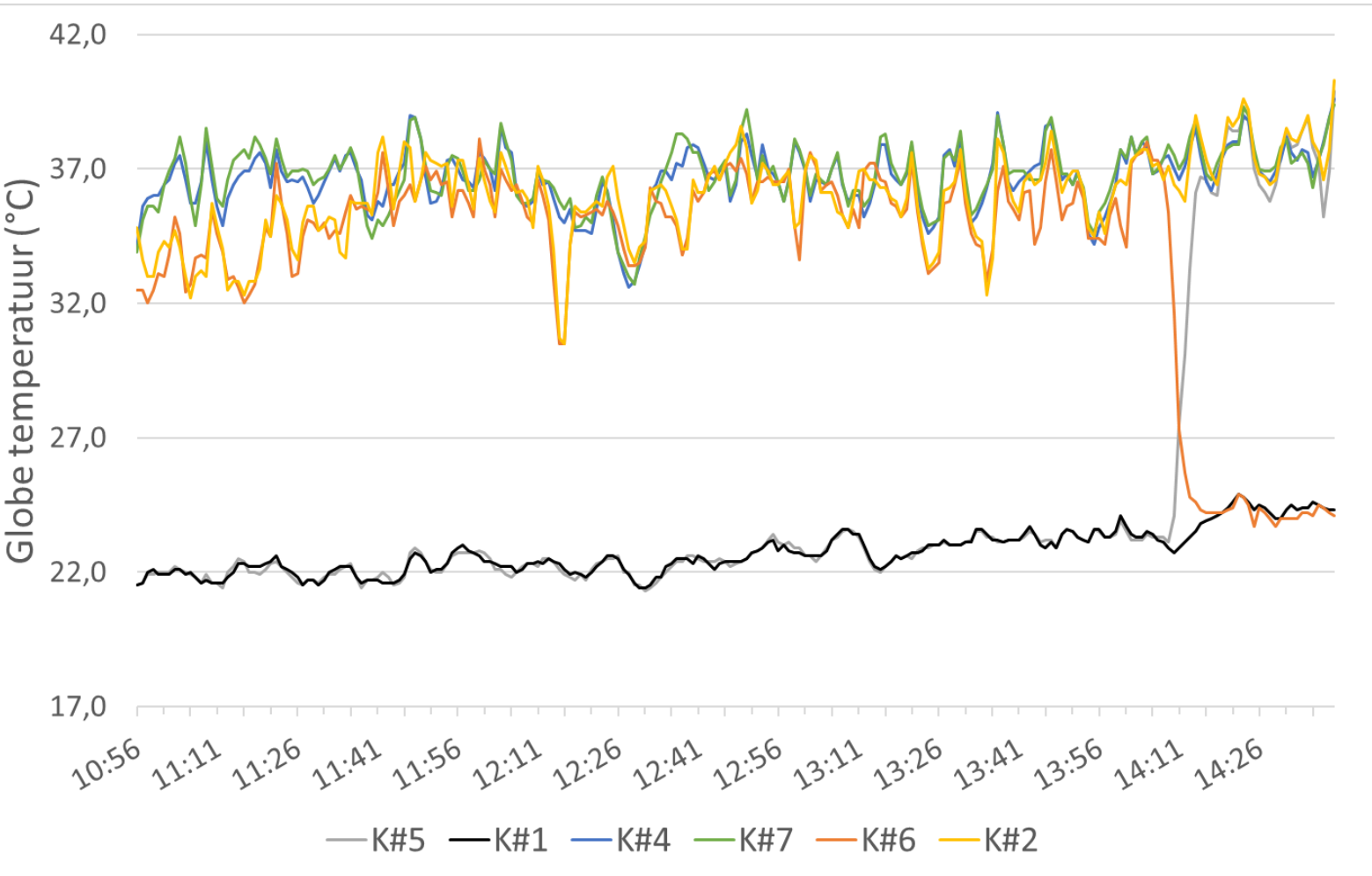

Period: 10:56-14:06 h

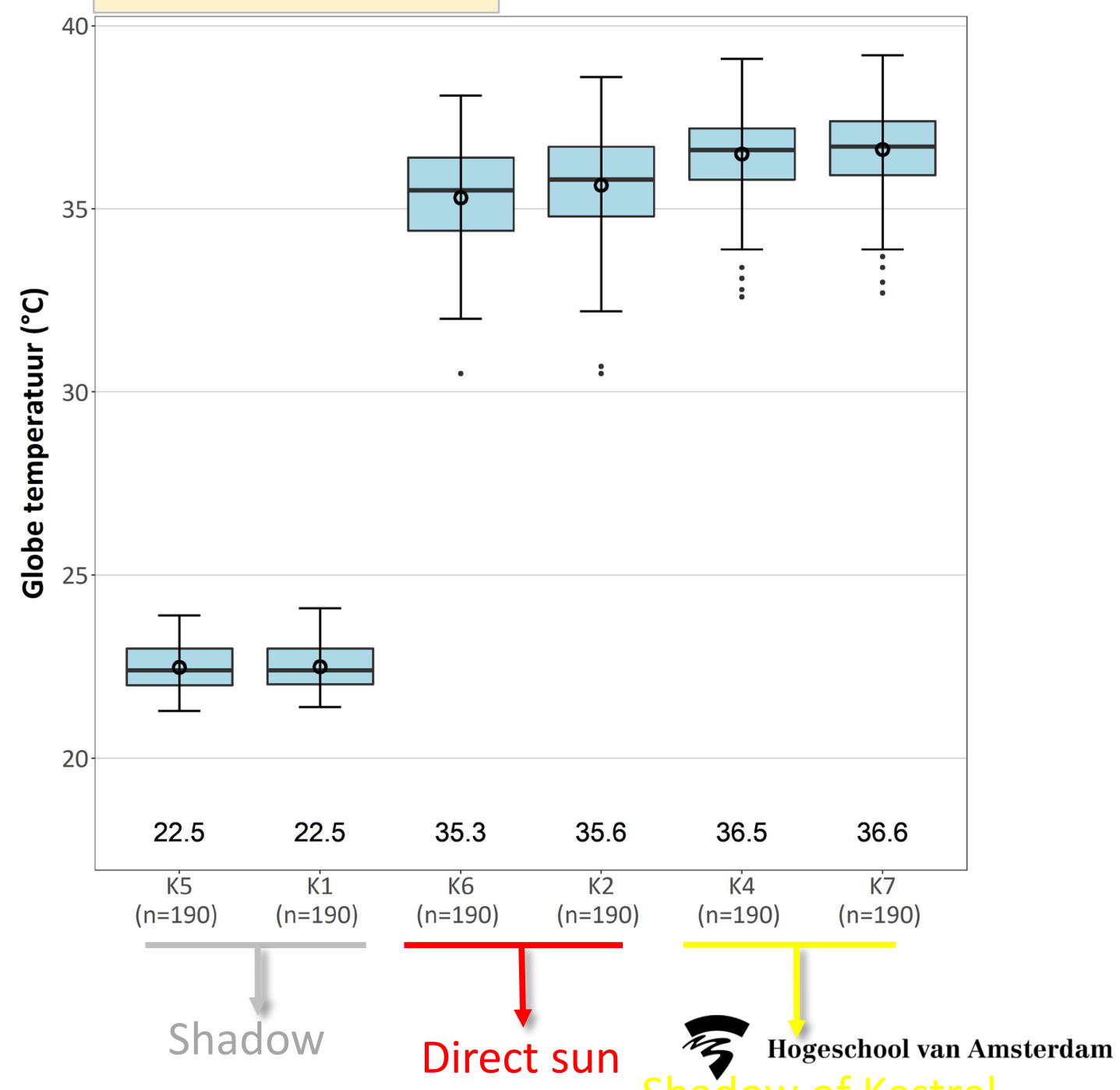




\section{Results - Wind speed}

\section{2nd experiment: Stadionplein}

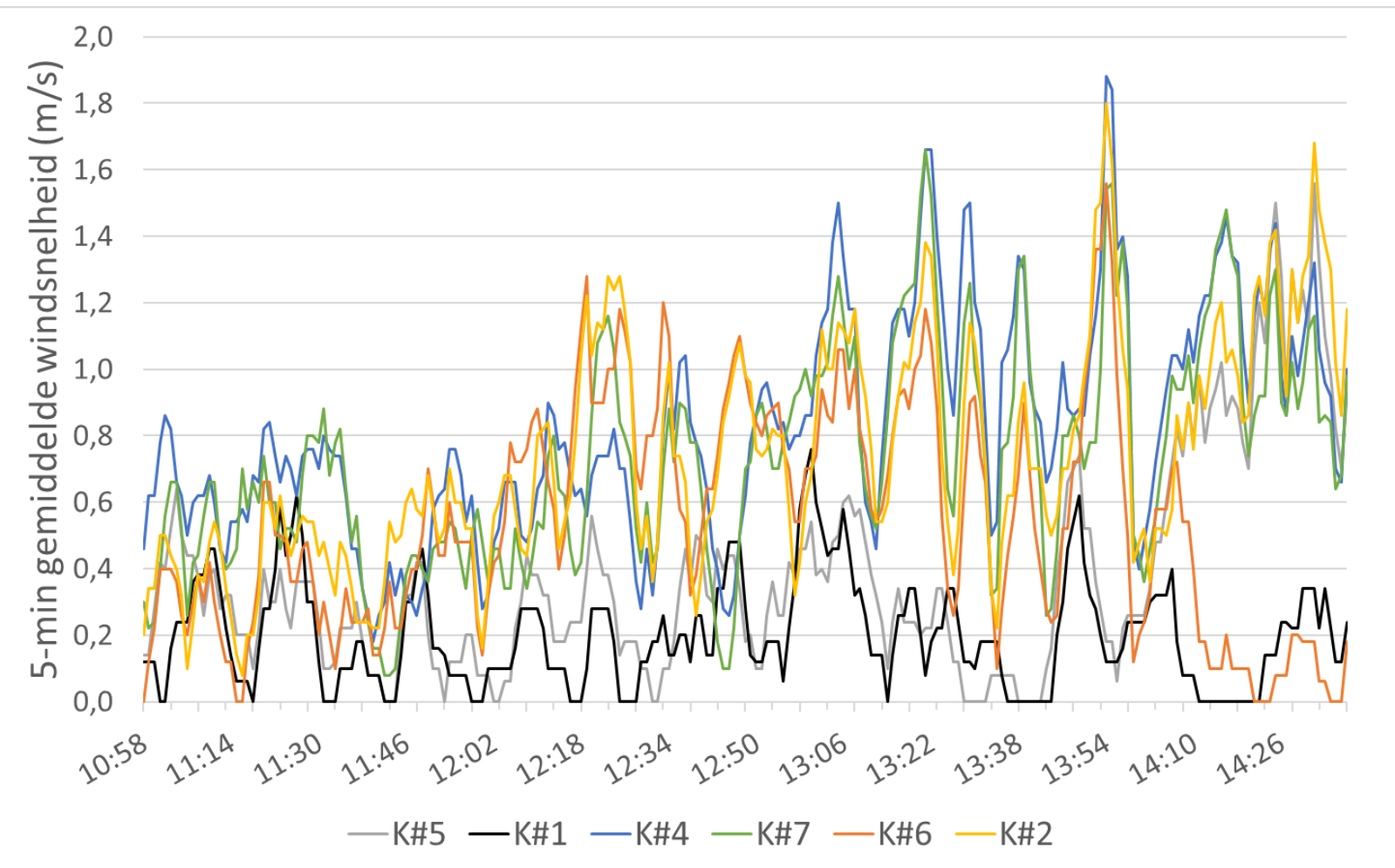

K\#5 \& K\#1: shadow $K \# 4$ \& $K \# 7$ : shadow of Kestrel K\#6 \& K\#2: direct sun
Period: 10:56-14:06 h

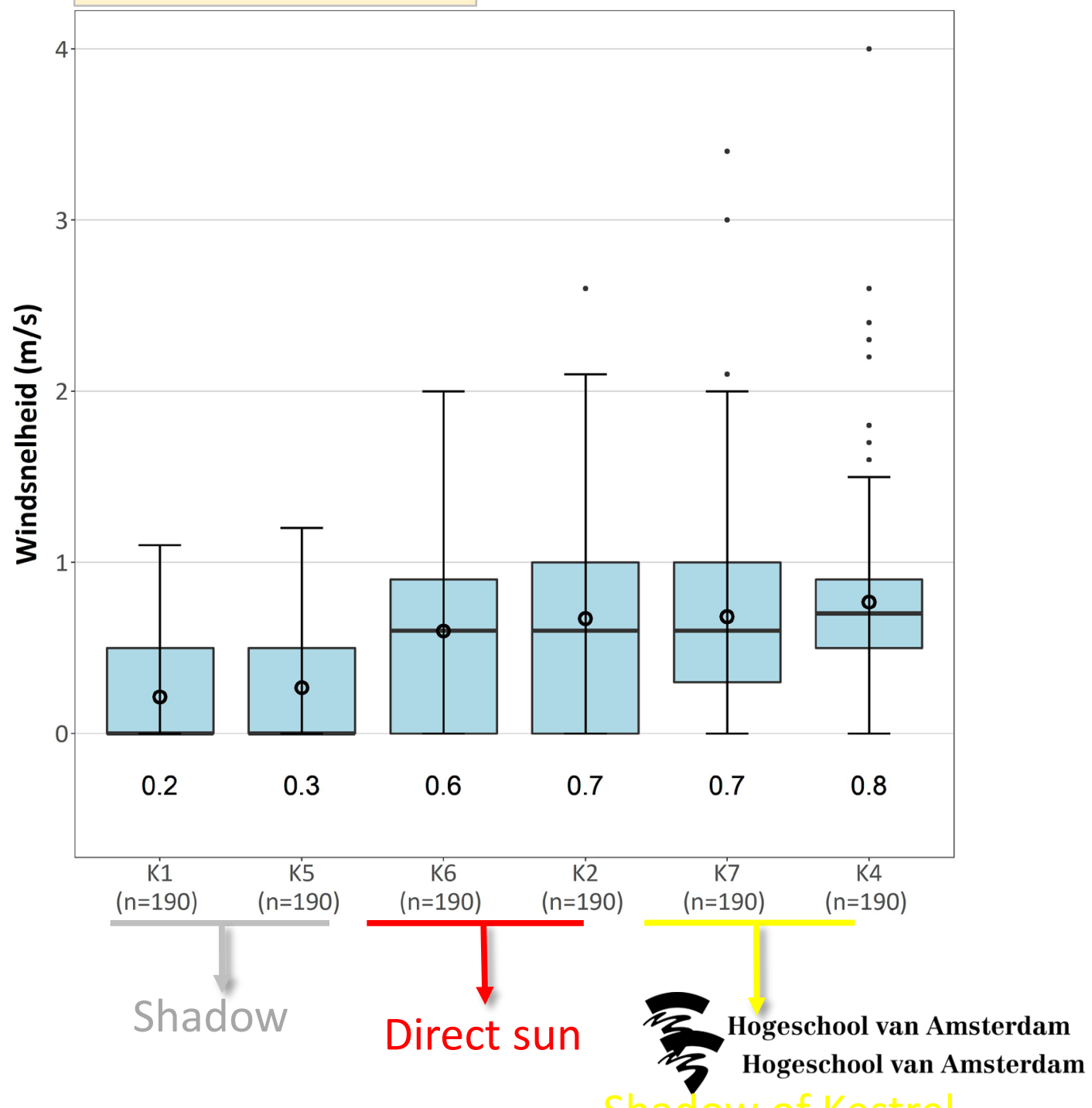




\section{Results - Humidity}

2nd experiment: Stadionplein

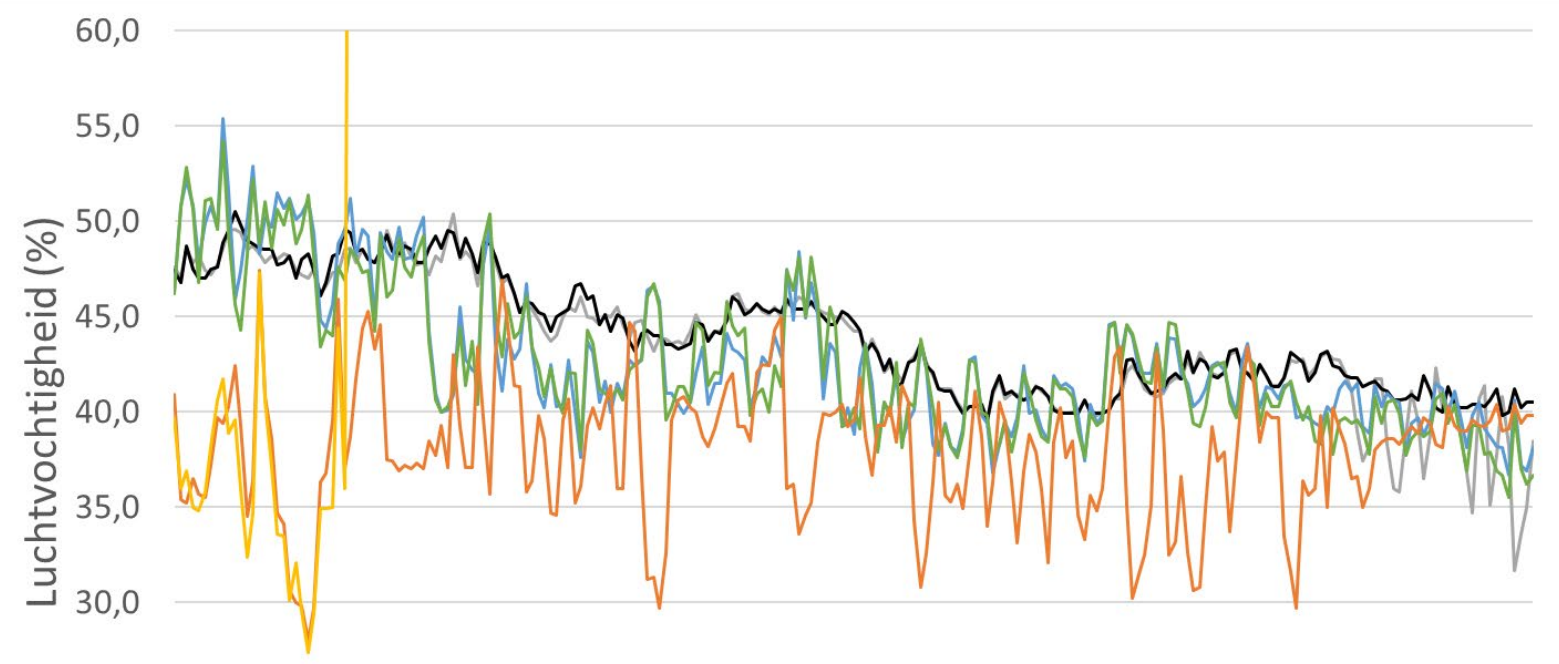

25,0

20,0

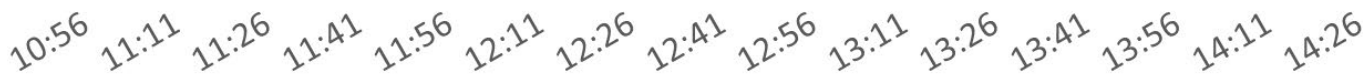

$$
\begin{aligned}
& \text {-K\#5 -K\#1 - K\#4-K\#7-K\#6-K\#2 }
\end{aligned}
$$

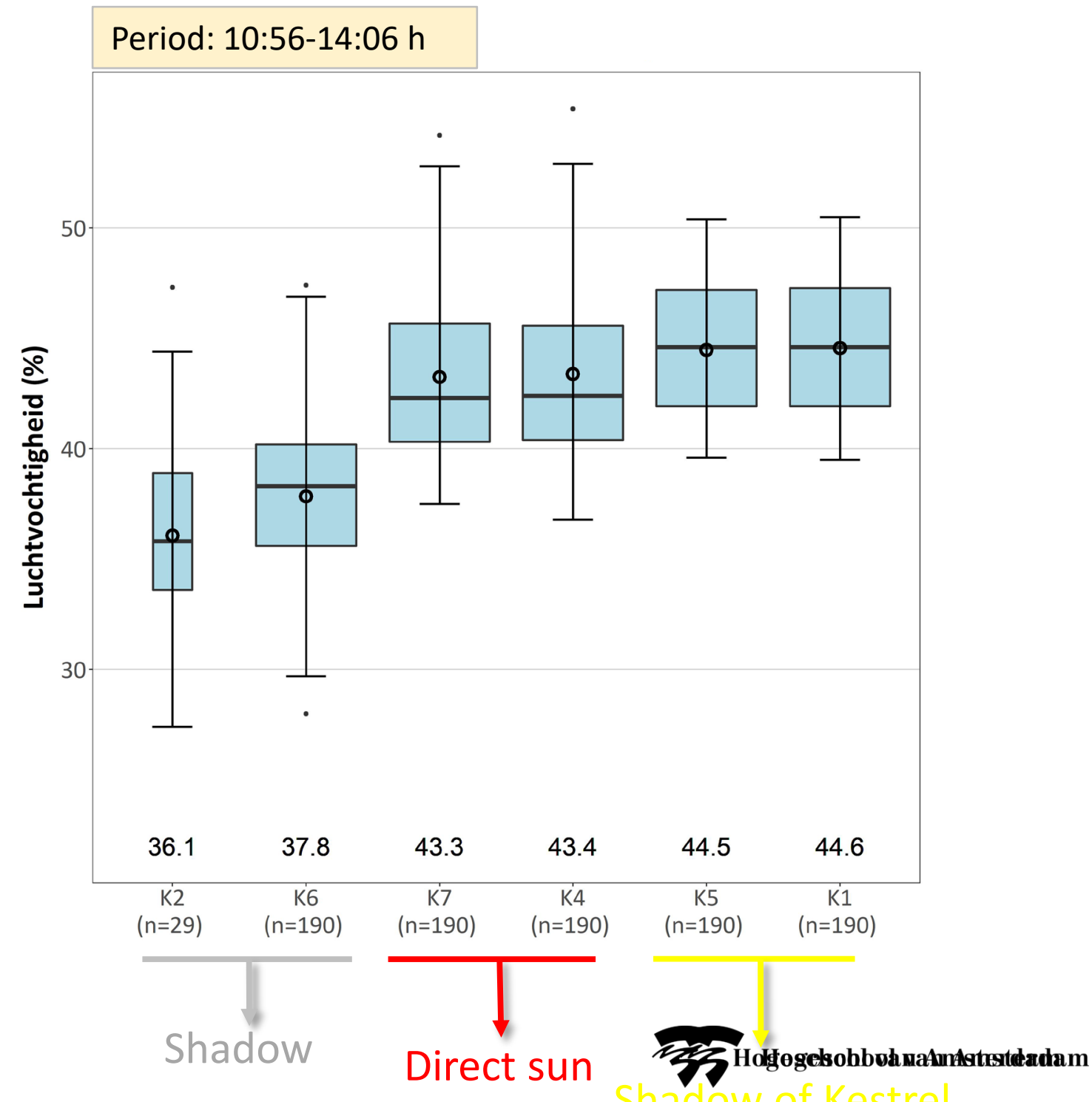




\section{Results - 10-min average MRT}

2nd experiment: Stadionplein

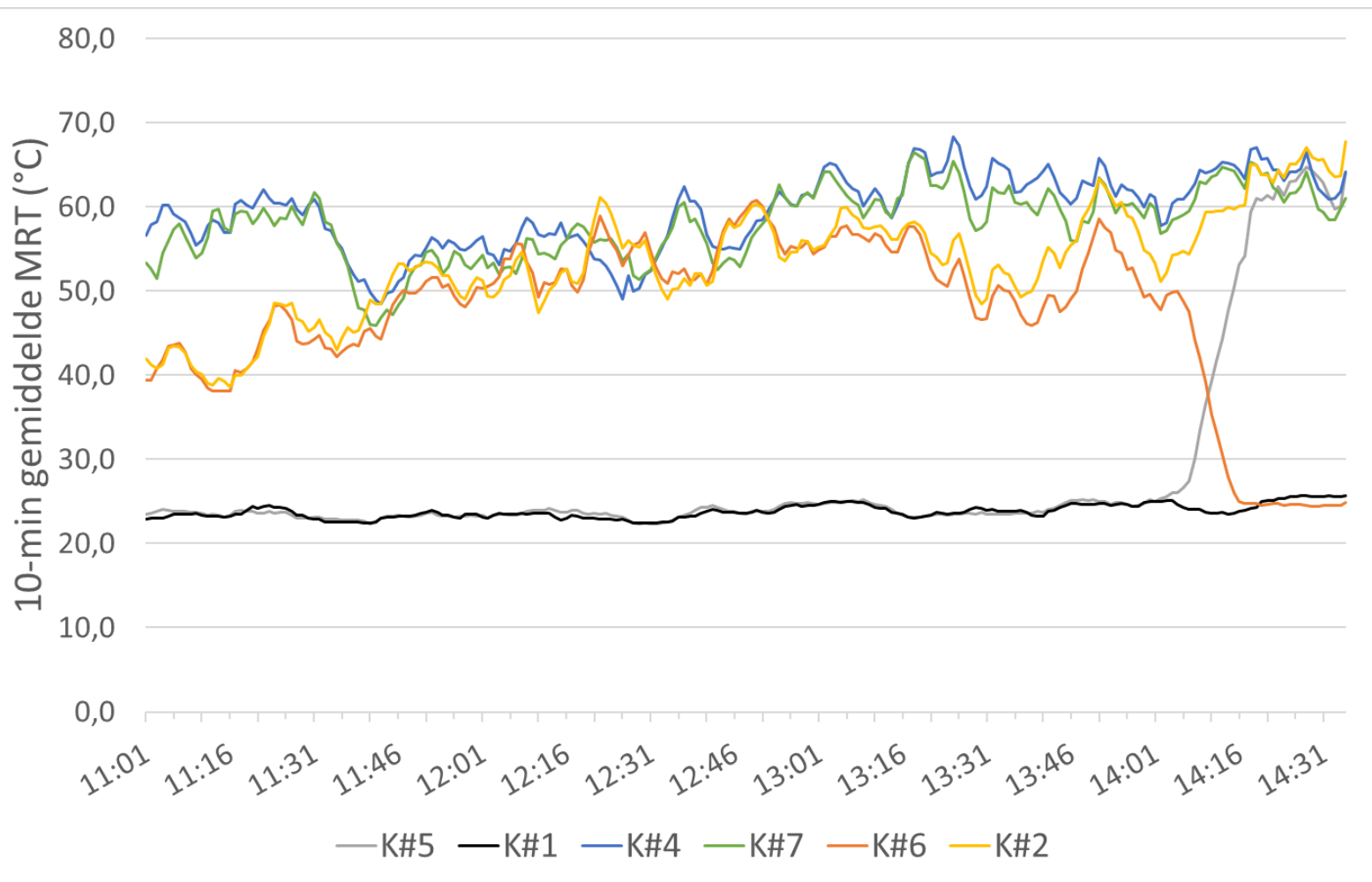

K\#5 \& K\#1: shadow

: shadow of kestrel

K\#6 \& K\#2: direct sun

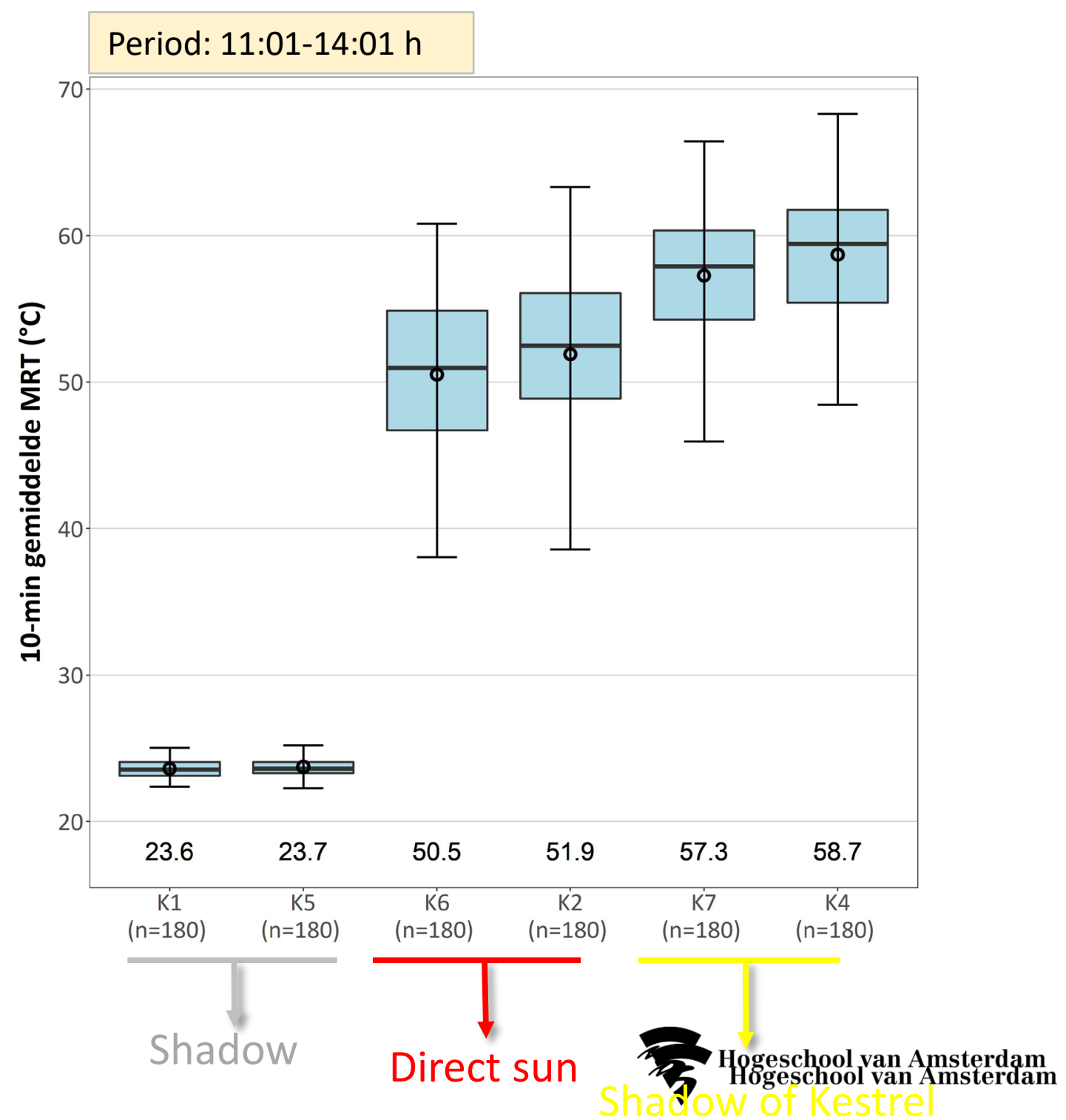




\section{Results - 10-min average PET}

2nd experiment: Stadionplein

$$
45,0
$$

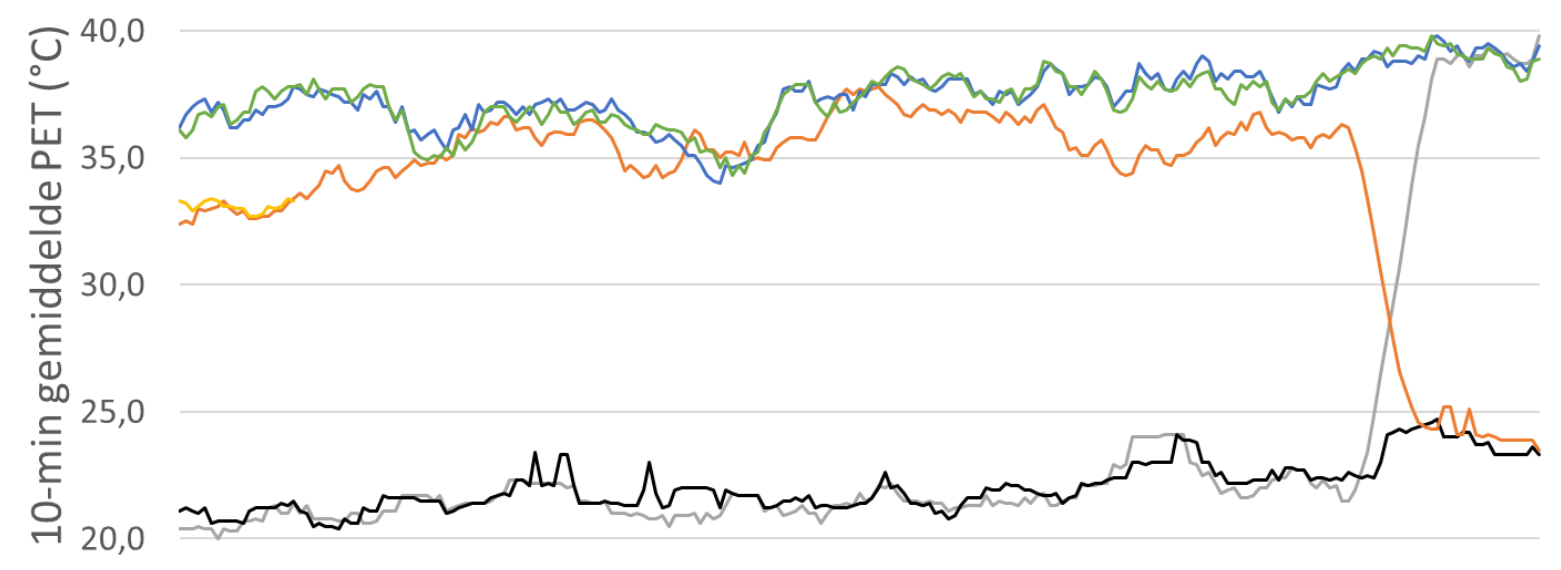

15,0

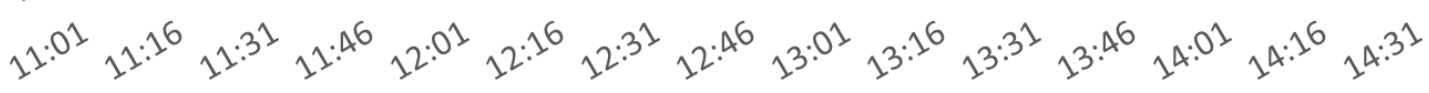

$$
\begin{aligned}
& \text { - К\#5 - К\#1 - К\#6 - К\#2 - К\#4 - К\#7 }
\end{aligned}
$$

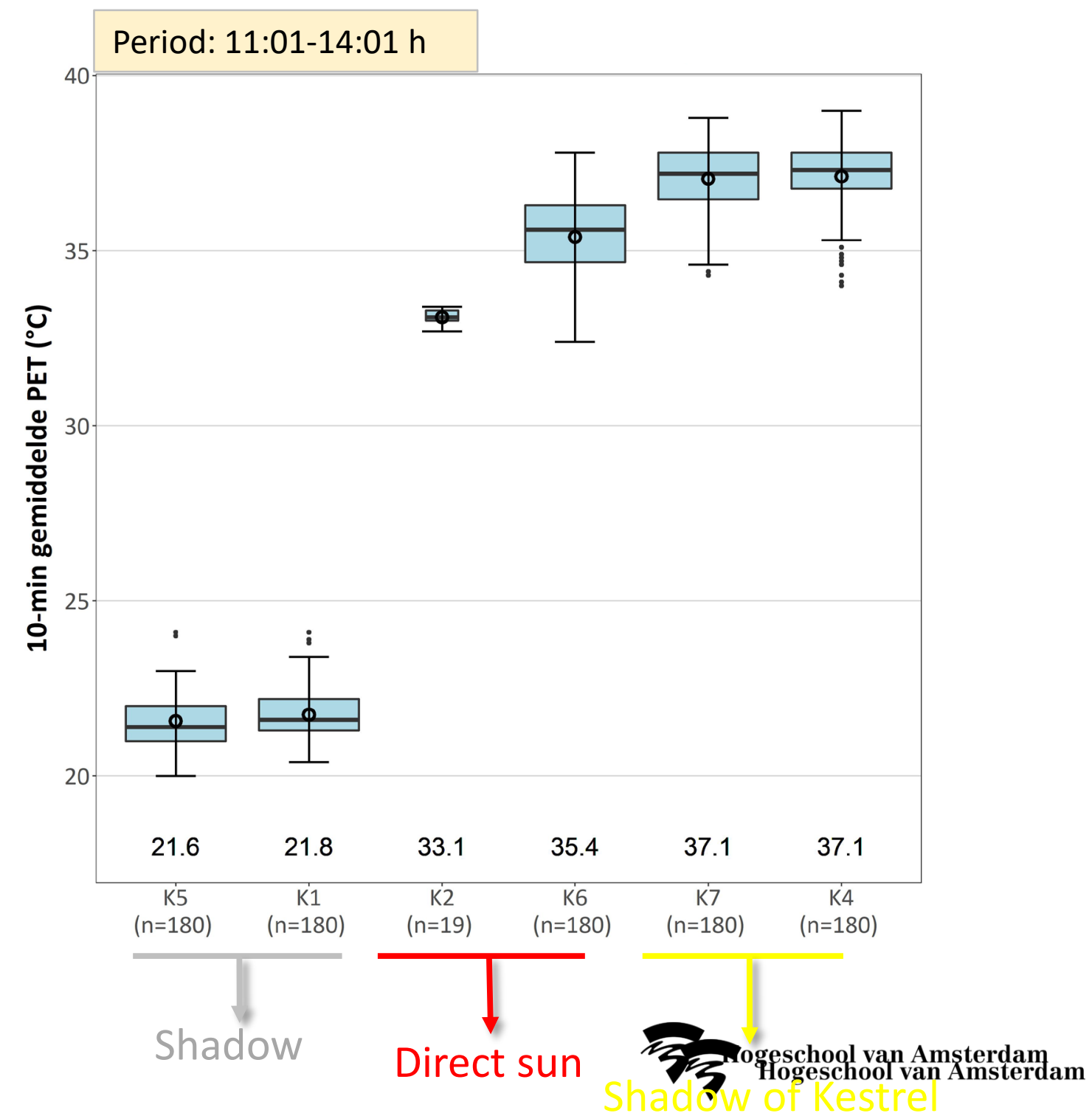




\section{Results}

2nd experiment proef: Stadionplein

\begin{tabular}{|c|c|c|c|c|c|c|c|c|c|}
\hline & & \begin{tabular}{|c|} 
Luchttemperatuur \\
$\left({ }^{\circ} \mathrm{C}\right)$
\end{tabular} & $\begin{array}{c}\text { Luchtvochtigheid } \\
(\%) \\
\end{array}$ & \begin{tabular}{|c|} 
Windsnelheid \\
$(\%)$
\end{tabular} & \begin{tabular}{|c|}
$\begin{array}{c}\text { Globetemperatuur } \\
\left({ }^{\circ} \mathrm{C}\right)\end{array}$ \\
\end{tabular} & $\begin{array}{c}\text { 5-min MRT } \\
\left({ }^{\circ} \mathrm{C}\right) \\
\end{array}$ & $\begin{array}{c}\text { 10-min MRT } \\
\left({ }^{\circ} \mathrm{C}\right) \\
\end{array}$ & $\begin{array}{c}\text { 5-min PET } \\
\left({ }^{\circ} \mathrm{C}\right) \\
\end{array}$ & $\begin{array}{c}\text { 10-min PET } \\
\left({ }^{\circ} \mathrm{C}\right) \\
\end{array}$ \\
\hline \multirow{2}{*}{ Shadow } & Kestrel \#5 & $21,3 \pm 0,7$ & $44,5 \pm 2,9$ & $0,3 \pm 0,3$ & $22,5 \pm 0,6$ & $23,7 \pm 1,0$ & $23,7 \pm 0,8$ & $21,6 \pm 0,9$ & $21,6 \pm 0,8$ \\
\hline & Kestrel \#1 & $21,2 \pm 0,7$ & $44,6 \pm 2,9$ & $0,2 \pm 0,3$ & $22,5 \pm 0,6$ & $23,6 \pm 1,0$ & $23,6 \pm 0,7$ & $21,9 \pm 0,9$ & $21,8 \pm 0,7$ \\
\hline \multirow{2}{*}{$\begin{array}{l}\text { Shadow of } \\
\text { Kestrel }\end{array}$} & Kestrel \#4 & $22,4 \pm 1,3$ & $43,4 \pm 3,9$ & $0,8 \pm 0,6$ & $36,5 \pm 1,1$ & $58,5 \pm 5,7$ & $58,7 \pm 4,3$ & $37,0 \pm 1,3$ & $37,1 \pm 1,0$ \\
\hline & Kestrel \#7 & $22,6 \pm 1,2$ & $43,3 \pm 3,7$ & $0,7 \pm 0,6$ & $36,6 \pm 1,2$ & $56,9 \pm 6,1$ & $57,3 \pm 4,1$ & $36,9 \pm 1,4$ & $37,1 \pm 1,0$ \\
\hline \multirow{2}{*}{ Direct sun } & Kestrel \#6 & $24,9 \pm 2,1$ & $37,8 \pm 3,8$ & $0,6 \pm 0,5$ & $35,3 \pm 1,5$ & $50,2 \pm 7,1$ & $50,5 \pm 5,4$ & $35,3 \pm 1,6$ & $35,4 \pm 1,3$ \\
\hline & Kestrel \#2 & $25,2 \pm 2,1$ & $36,1 \pm 4,5$ & $0,7 \pm 0,5$ & $35,6 \pm 1,5$ & $51,7 \pm 7,0$ & $51,9 \pm 5,7$ & $33,3 \pm 0,8$ & $33,1 \pm 0,2$ \\
\hline
\end{tabular}




\section{Conclusions based on experiment 2}

- According to the manufacturer, Kestrels are not suitable for measuring the air temperature when the Kestrel is being exposed to direct sunlight for a longer period of time. This is confirmed by our results: we concluded a difference in measured air temperature of $3,8^{\circ} \mathrm{C}$ for Kestrels in direct sunlight and in the shade.

- For an accurate measurement with the Kestrels it seems to be important to create a radiation screen (see next experiment) or to swing the Kestrels like the manufacturer mentioned in the FAQ.

- We also seem to conclude a difference in measured globe temperatures between Kestrels positioned in direct sunlight compared to those that are in direct sunlight but cast shade on their own temperature sensor. The globe temperature of the sensors that are in direct sunlight have a slightly lower globe temperature of 1 ${ }^{\circ} \mathrm{C}$, and a lower humidity, causing the PET-values toe be $2^{\circ} \mathrm{C}$ lower on average. This lower globe temperature is caused by the conversion of the 1 -inch to 6 -inch globe temperature values made by the Kestrels. In this calculation the Tmrt equation of Thorsson is used. Therefore, the globe temperature is influenced by the air temperature values: the higher the air temperature, the lower the globe temperature will be. 
Location: Stadionbuurt

$1 / 2$

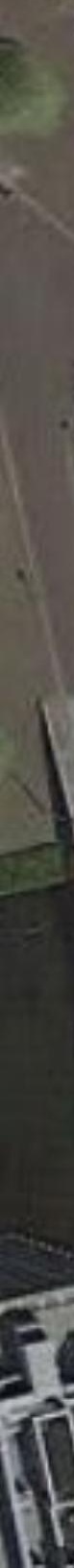




\section{Dutch weather report}

An:

\section{s.}

\section{Daggegevens van het weer in Nederland} Het weer op woensdag 24 juni 2020 te Schiphol

\section{Temperatuur}

Gemiddelde

Maximum

Minimum

Zon, bewolking \& zicht

Duur zonneschijn

Rel. zonneschijnduur

Gem. bedekkingsgraad

Minimaal zicht

\section{Normaal Neerslag}

$16.1^{\circ} \mathrm{C}$

Hoeveelheid

$0.0 \mathrm{~mm}$

$20.5^{\circ} \mathrm{C}$

Duur

0.0 uur

(c) KNMI

$28.9^{\circ} \mathrm{C}$

$11.4^{\circ} \mathrm{C}$

\section{Wind}

14.7 uur

$88 \%$

6 octa's

Zwaar bewolkt

$20.0 \mathrm{~km}$

Gemiddelde snelheid

$41 \%$ Maximale uurgemiddelde snelheid Maximale stoot

Overheersende richting

Luchtdruk

Gemiddelde luchtdruk
$4.4 \mathrm{~m} / \mathrm{s}$
$6.0 \mathrm{~m} / \mathrm{s}$
$9.0 \mathrm{~m} / \mathrm{s}$

(3 Bft)

(4 Bft)

$75^{\circ}$

(O)

\section{Relatieve luchtvochtigheid}

Gemiddelde 


\section{Set up}

Start time: 2 30 End tine 16.0.

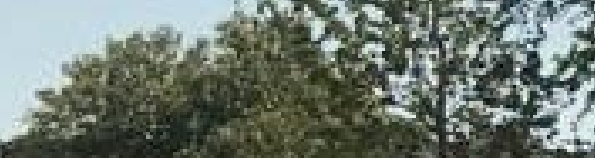
3.
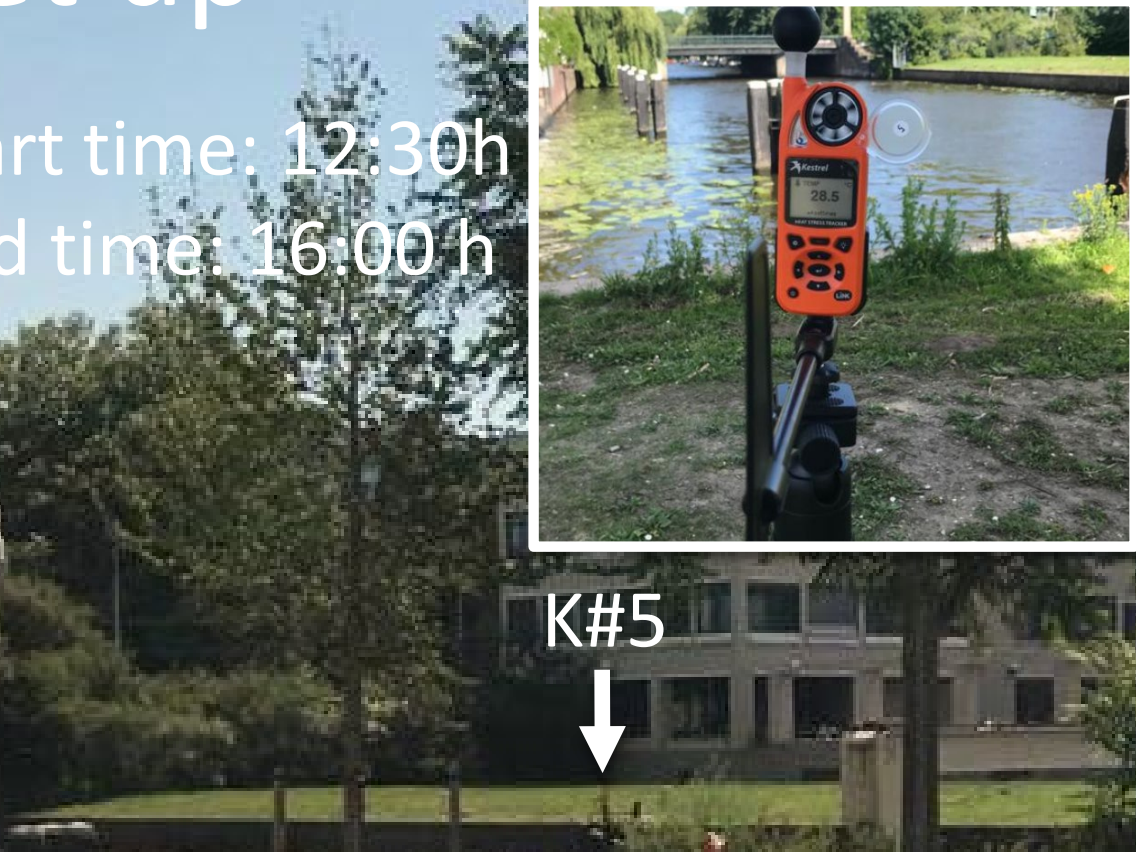

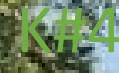
Sunn tvane mount

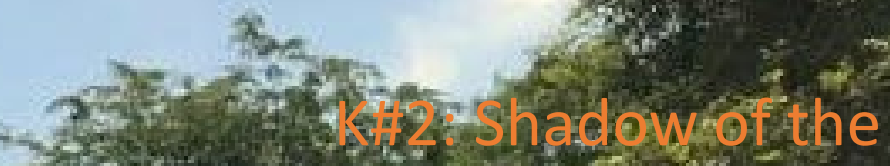

$$
\text { - }
$$
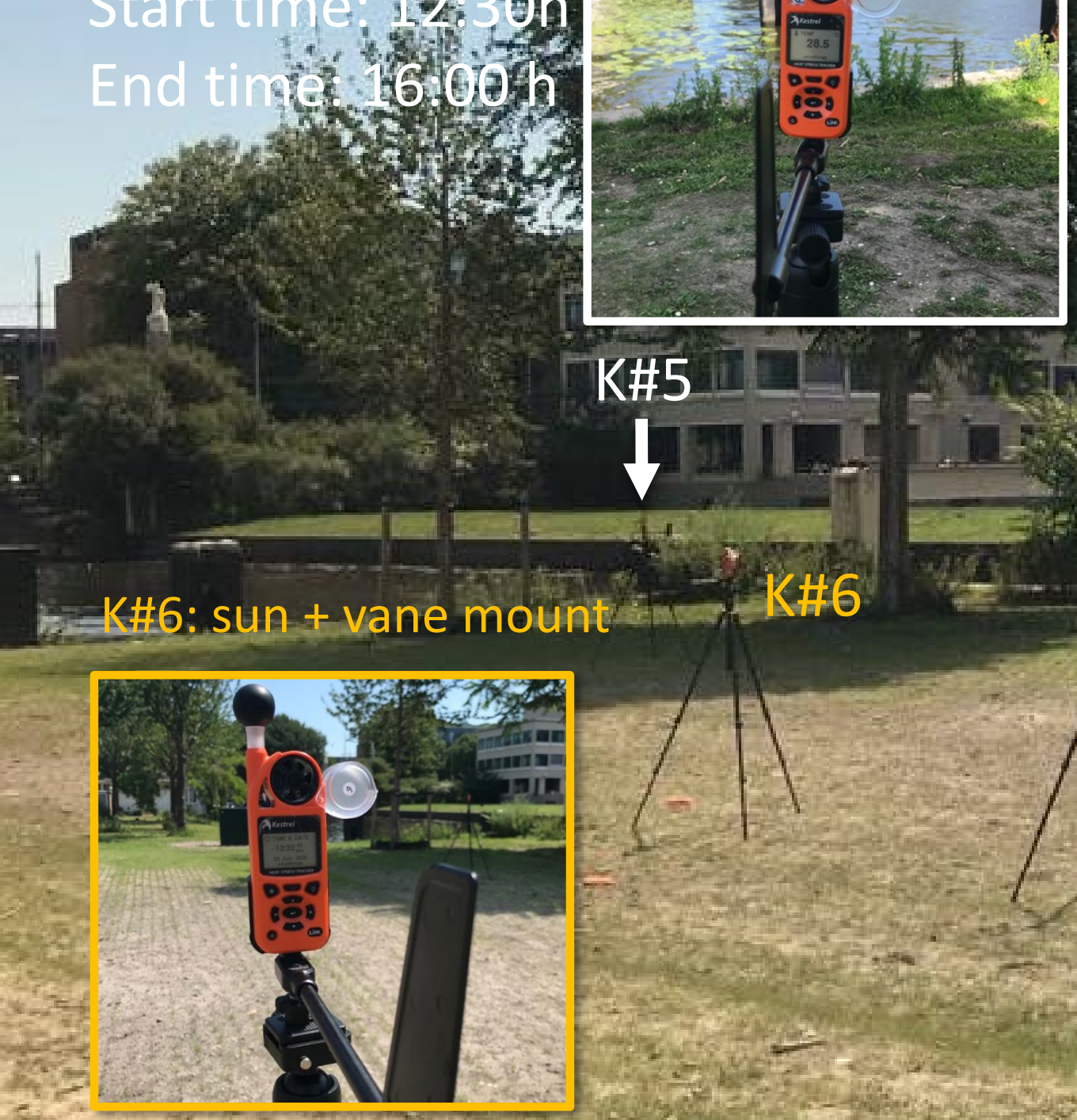

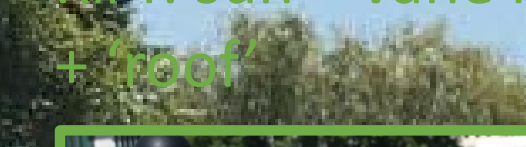
K\#7: direct
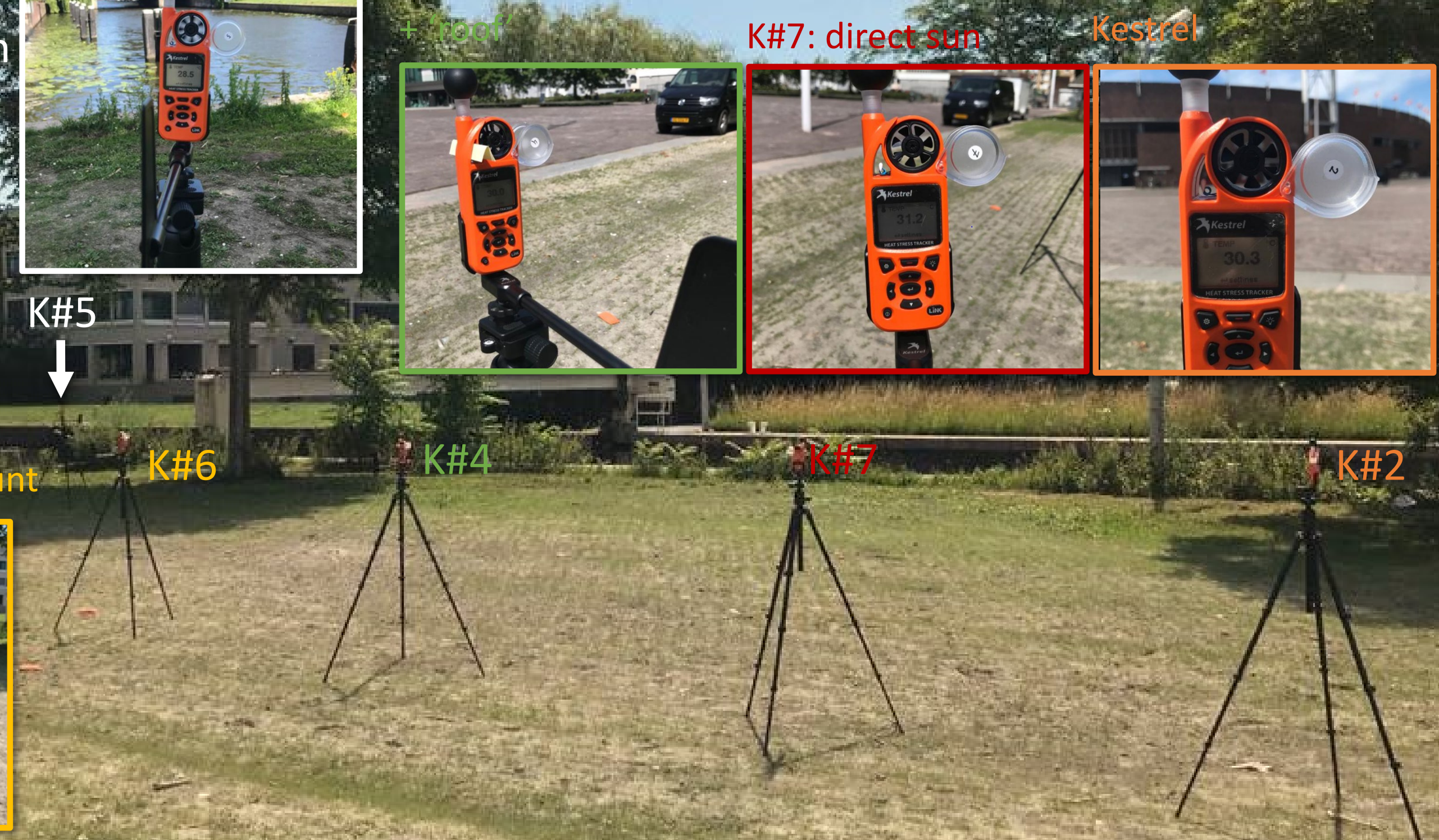

Hogeschool van Amsterdam
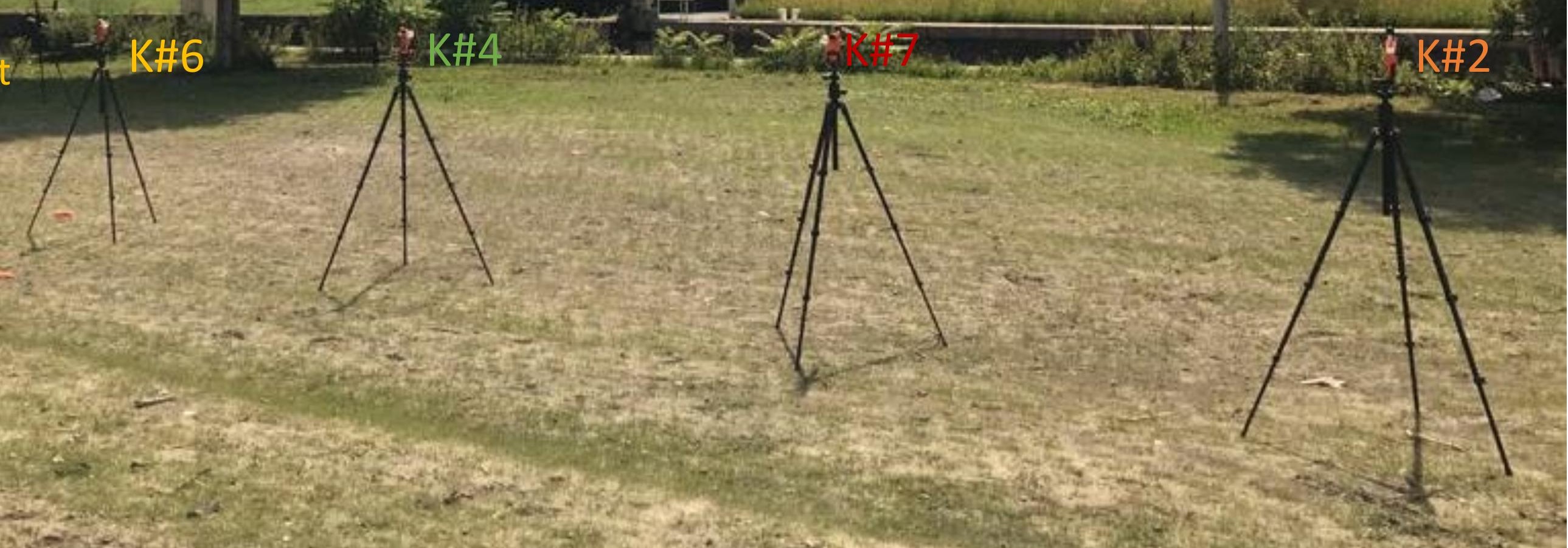

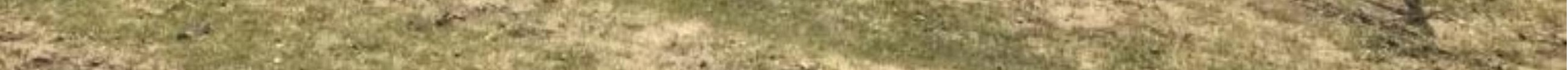




\section{Results - air temperature}

\section{3rd experiment: Stadionbuurt}

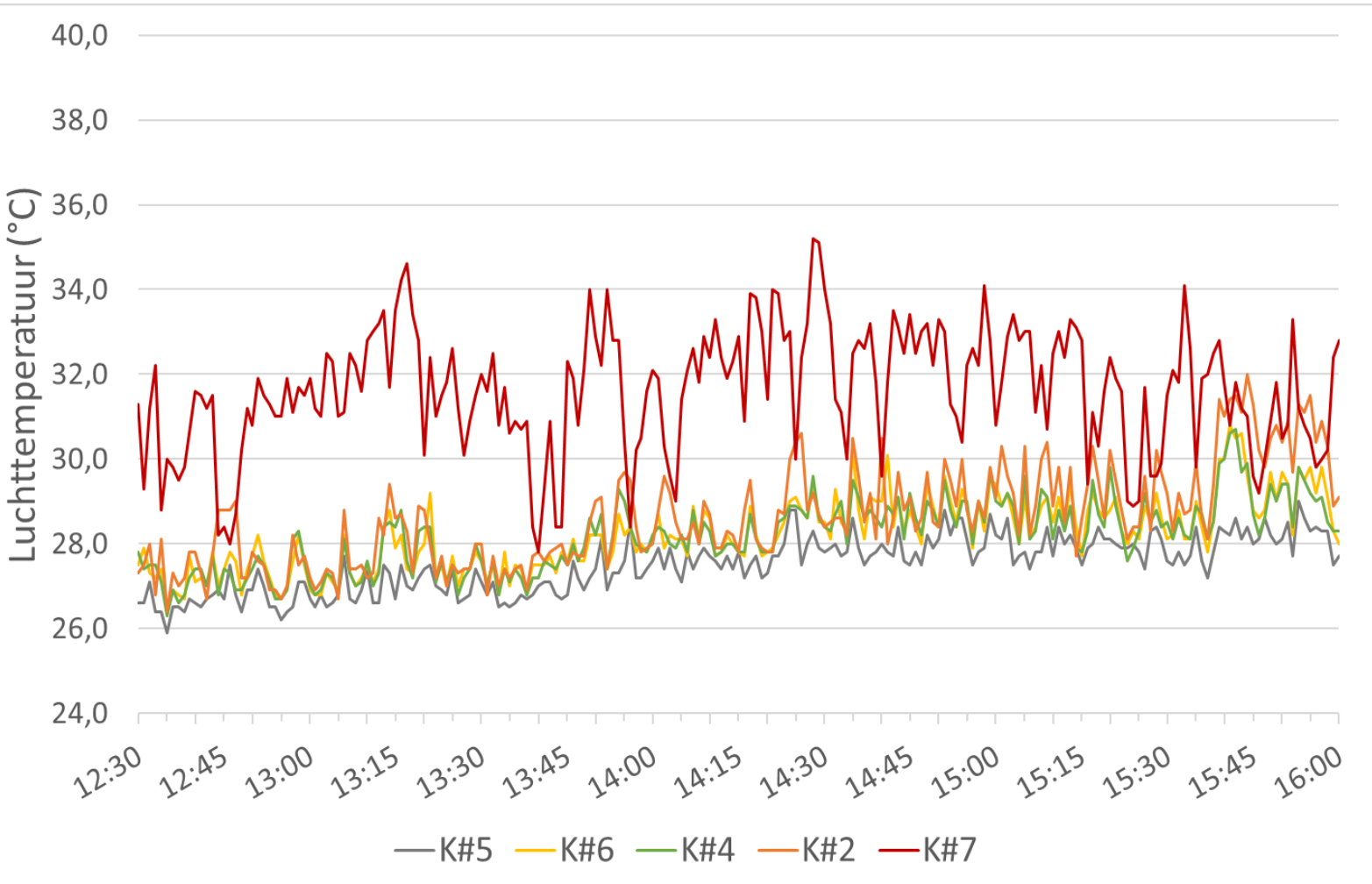

K\#5: shadow + vane mount K\#6: sun + vane mount K\#4: sun + vane mount + roof K\#2: sun + shadow of Kestrel K\#7: direct sun

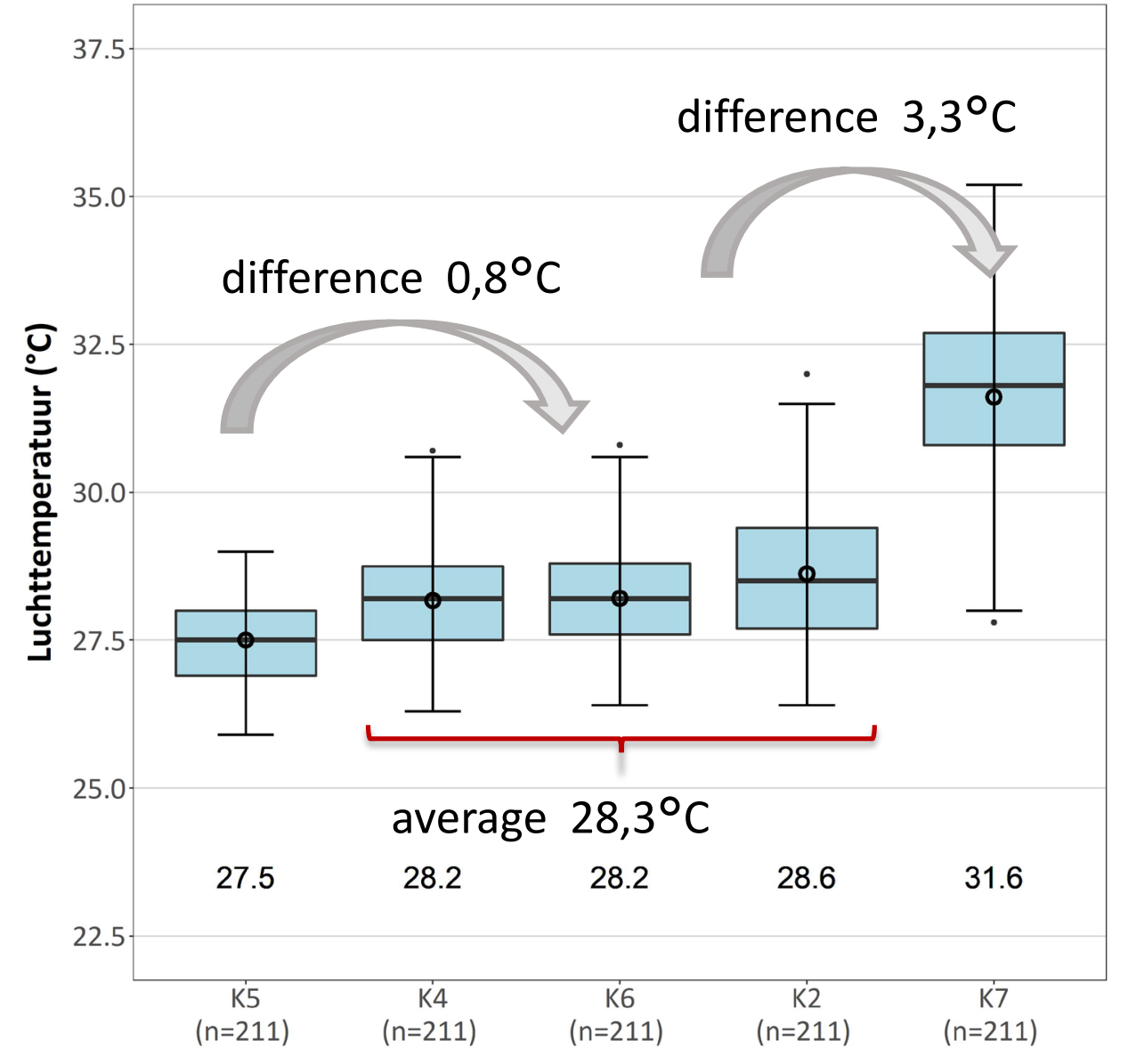




\section{Results - windspeed}

3rd experiment: Stadionbuurt$$
\text { ज्ञ }
$$

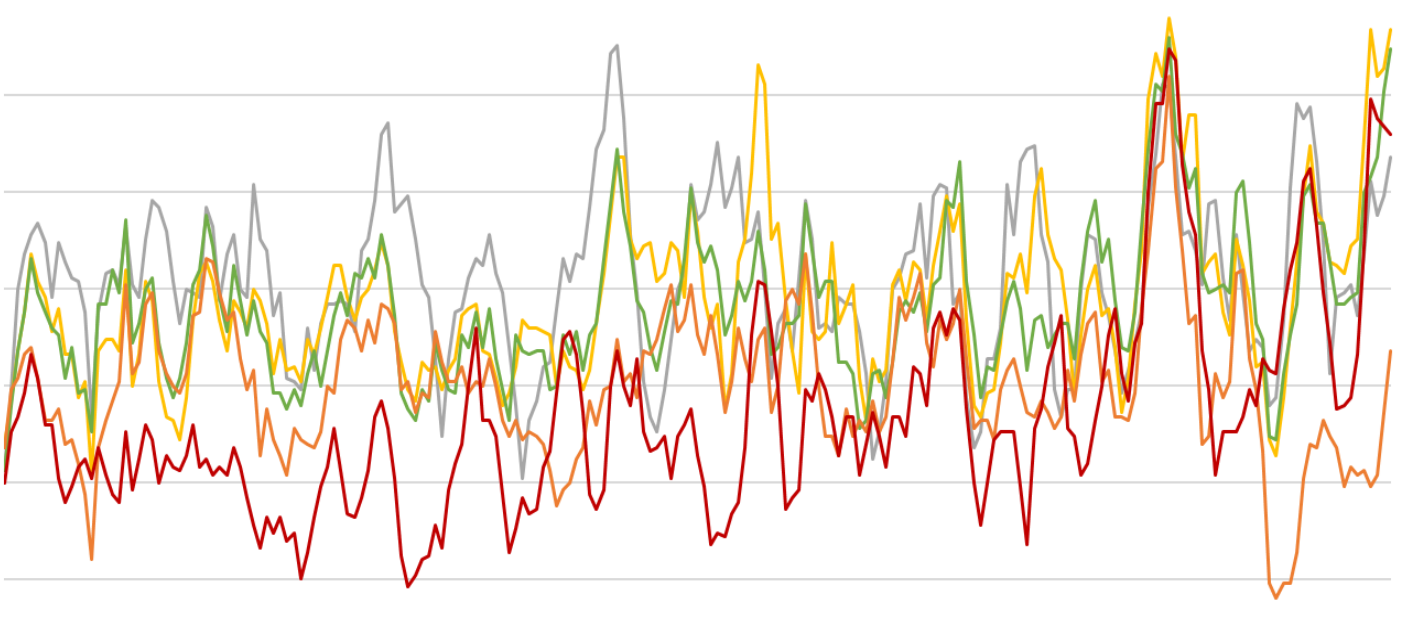

$$
0,0
$$

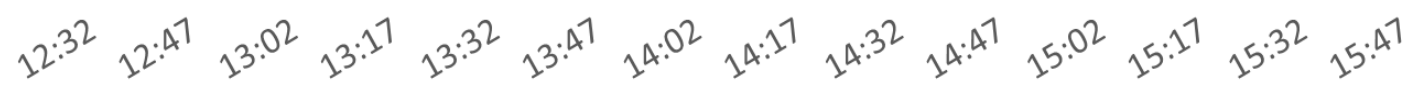$$
\text { -K\#5-K\#6 -K\#4 -K\#2 -K\#7 }
$$

K\#5: shadow + vane mount K\#6: sun + vane mount K\#4: sun + vane mount + roof K\#2: sun + shadow of Kestrel K\#7: direct sun

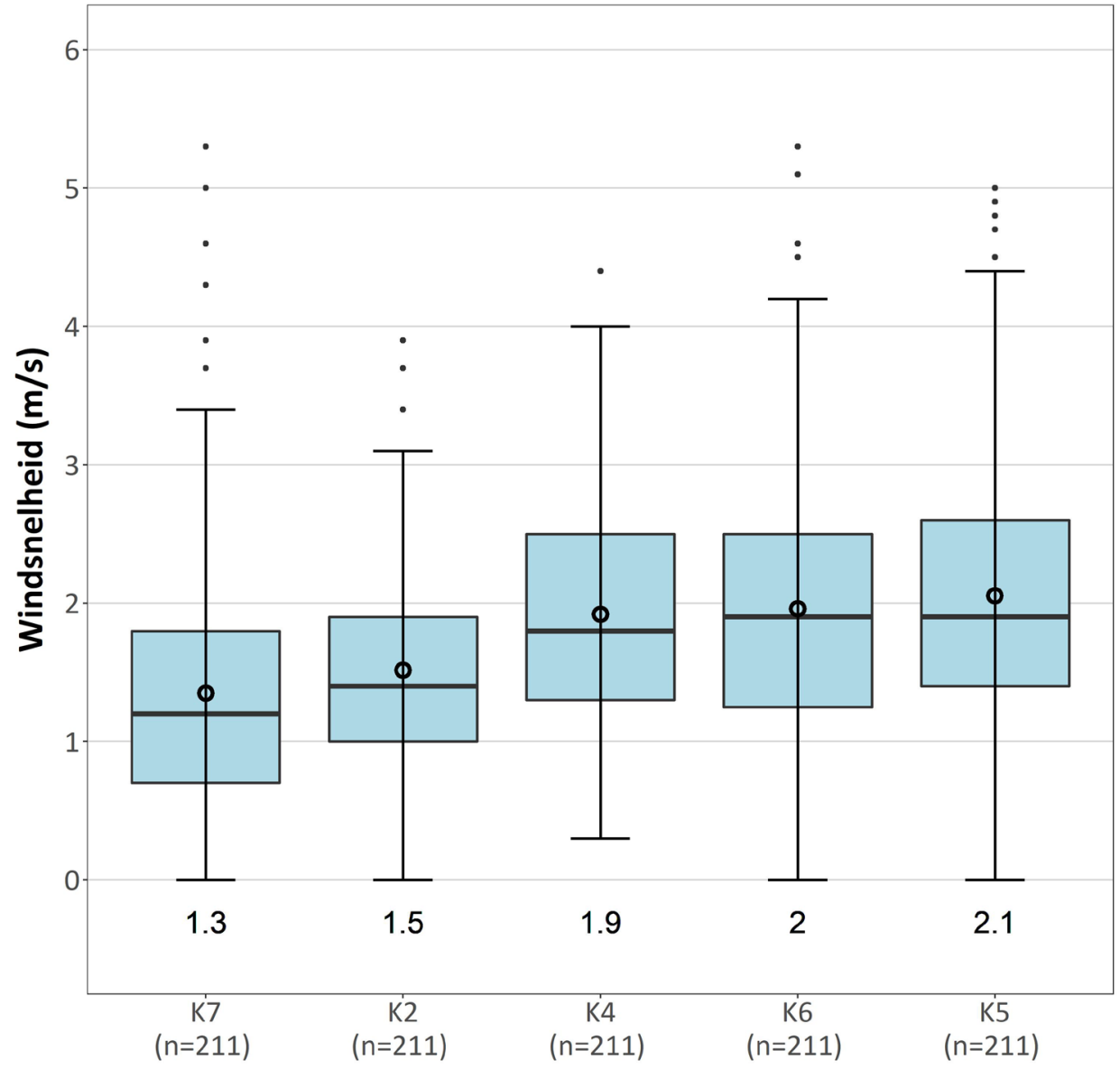




\section{Results - humidity}

\section{3rd experiment: Stadionbuurt}

45,0

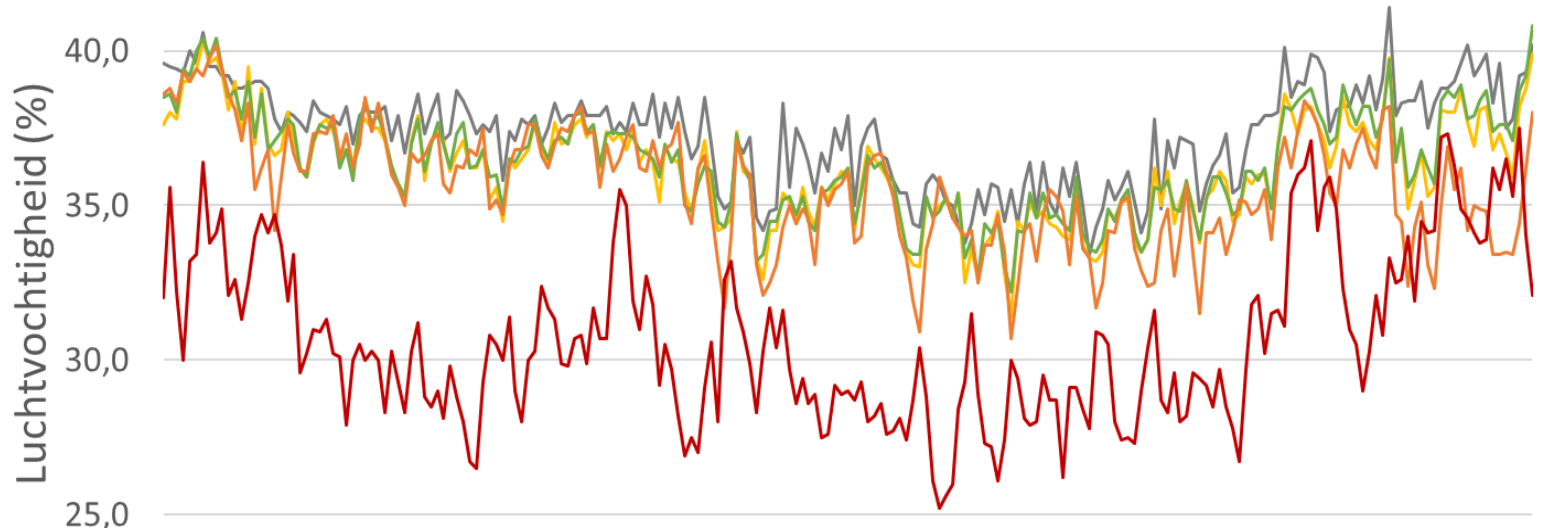

20,0

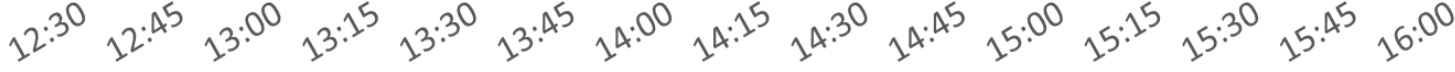

$$
\begin{aligned}
& \text {-K\#5 - К\#6 -К\#4 -К\#2 -К\#7 }
\end{aligned}
$$

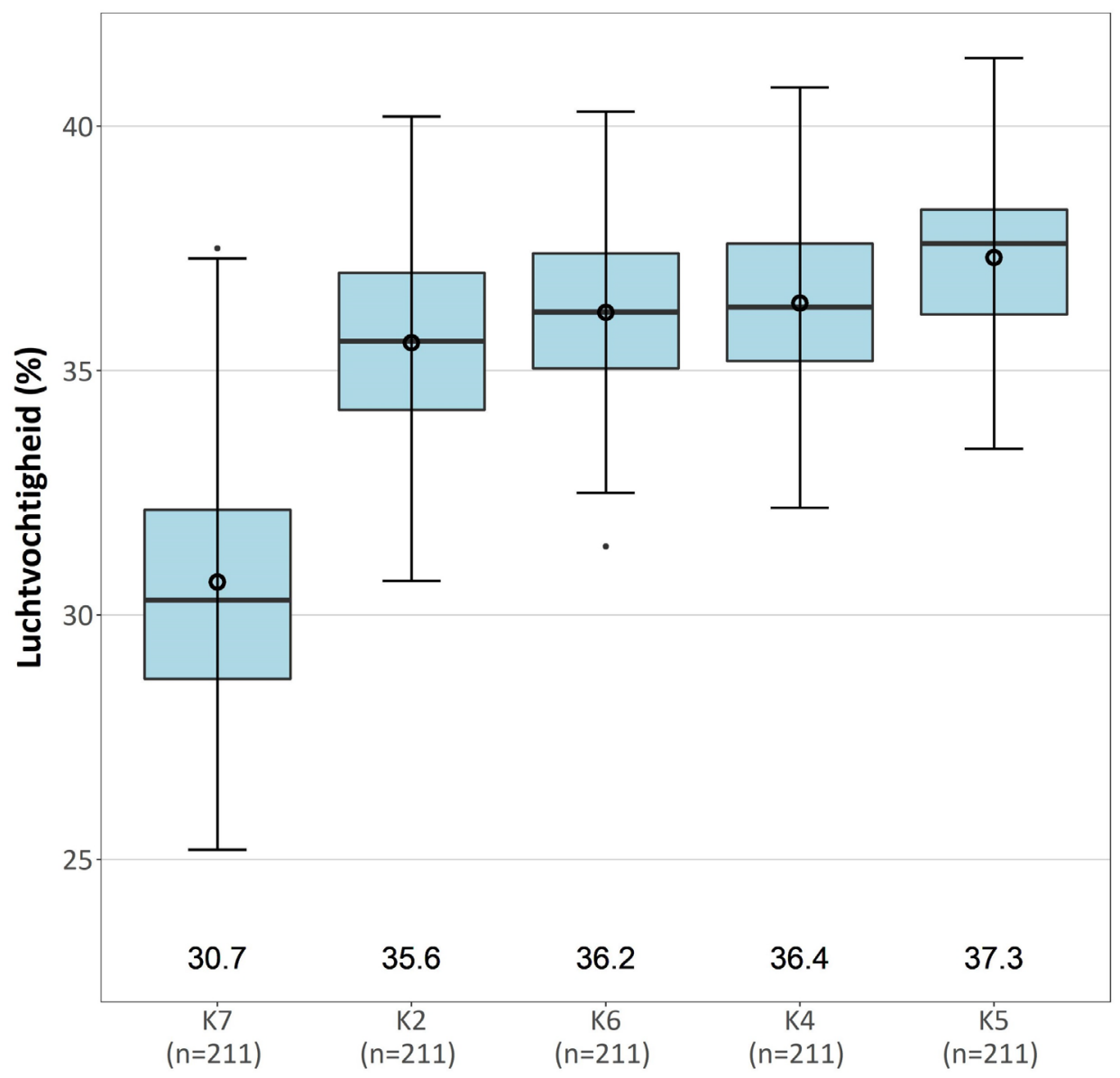

K\#4: sun + vane mount + roof

K\#2: sun + shadow of Kestrel

$\mathrm{K} \# 7$ : direct sun 


\section{Results - globe temperature}

\section{3rd experiment: Stadionbuurt}

50,0

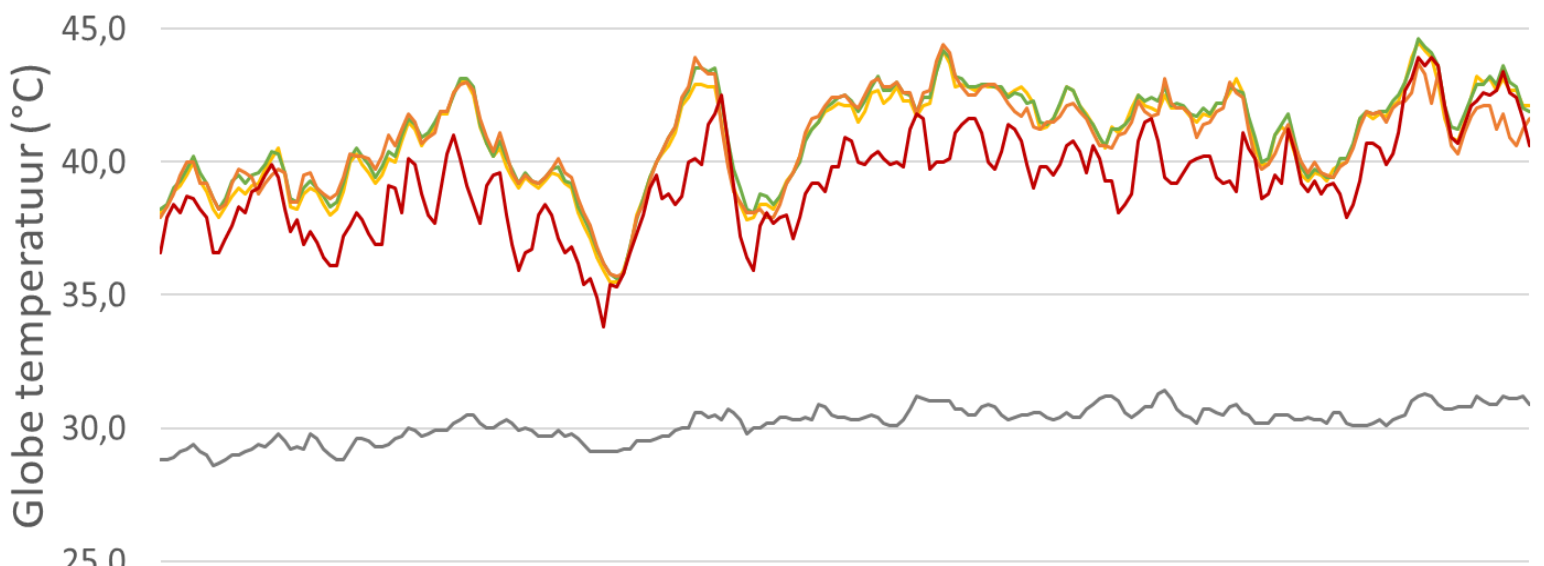

20,0

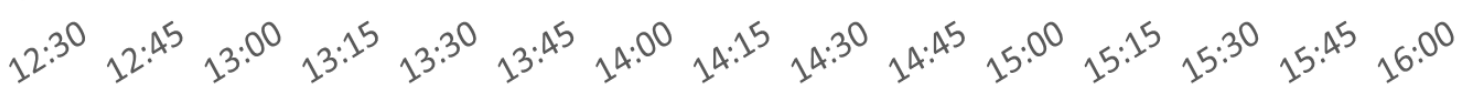
- К\#5 - К\#6 - К\#4 - К\#2 - К\#7

K\#5: shadow + vane mount K\#6: sun + vane mount K\#4: sun + vane mount + roof K\#2: sun + shadow of Kestrel K\#7: direct sun

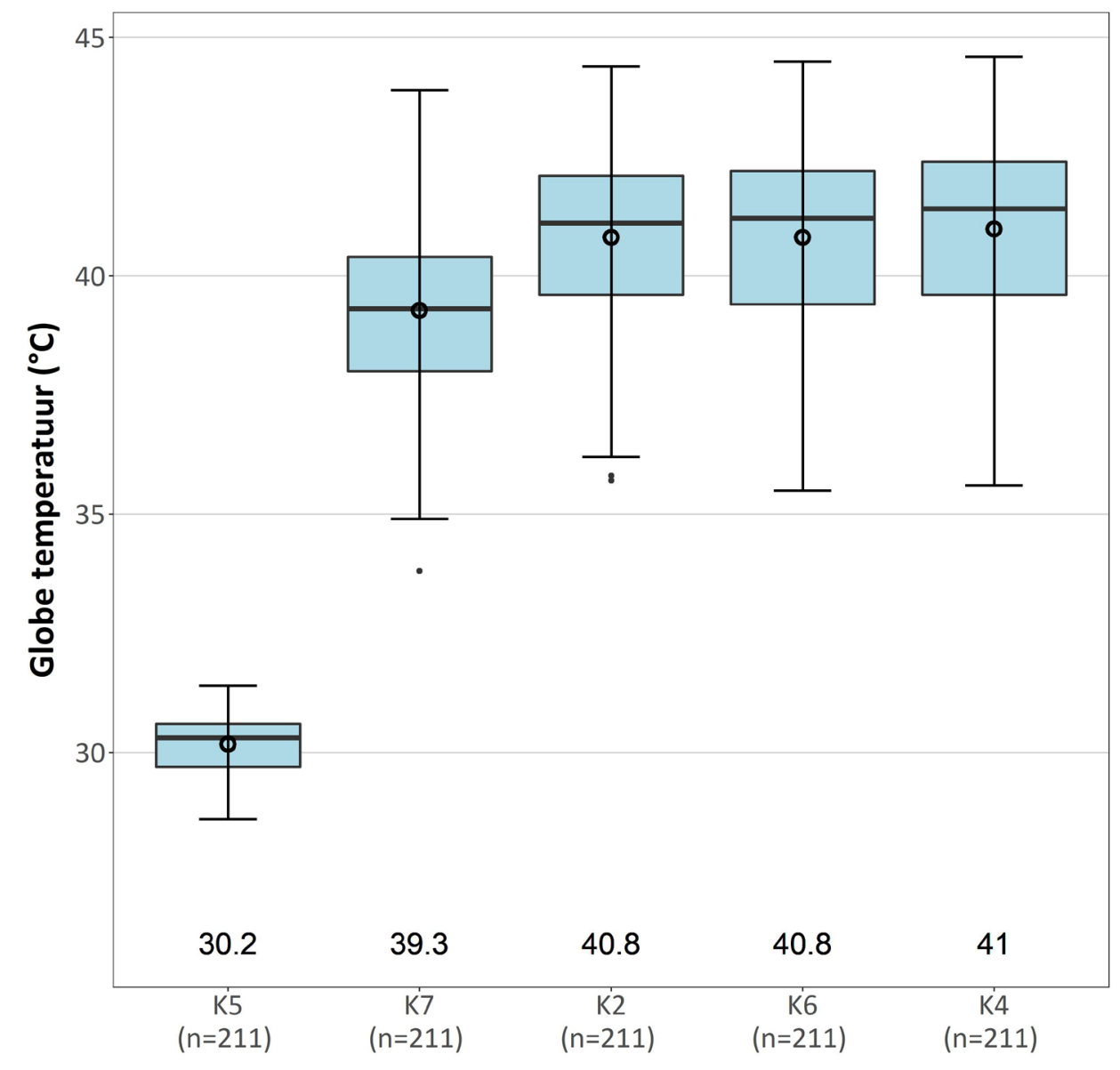




\section{Results - 10-min average MRT}

\section{3rd experiment: Stadionbuurt}

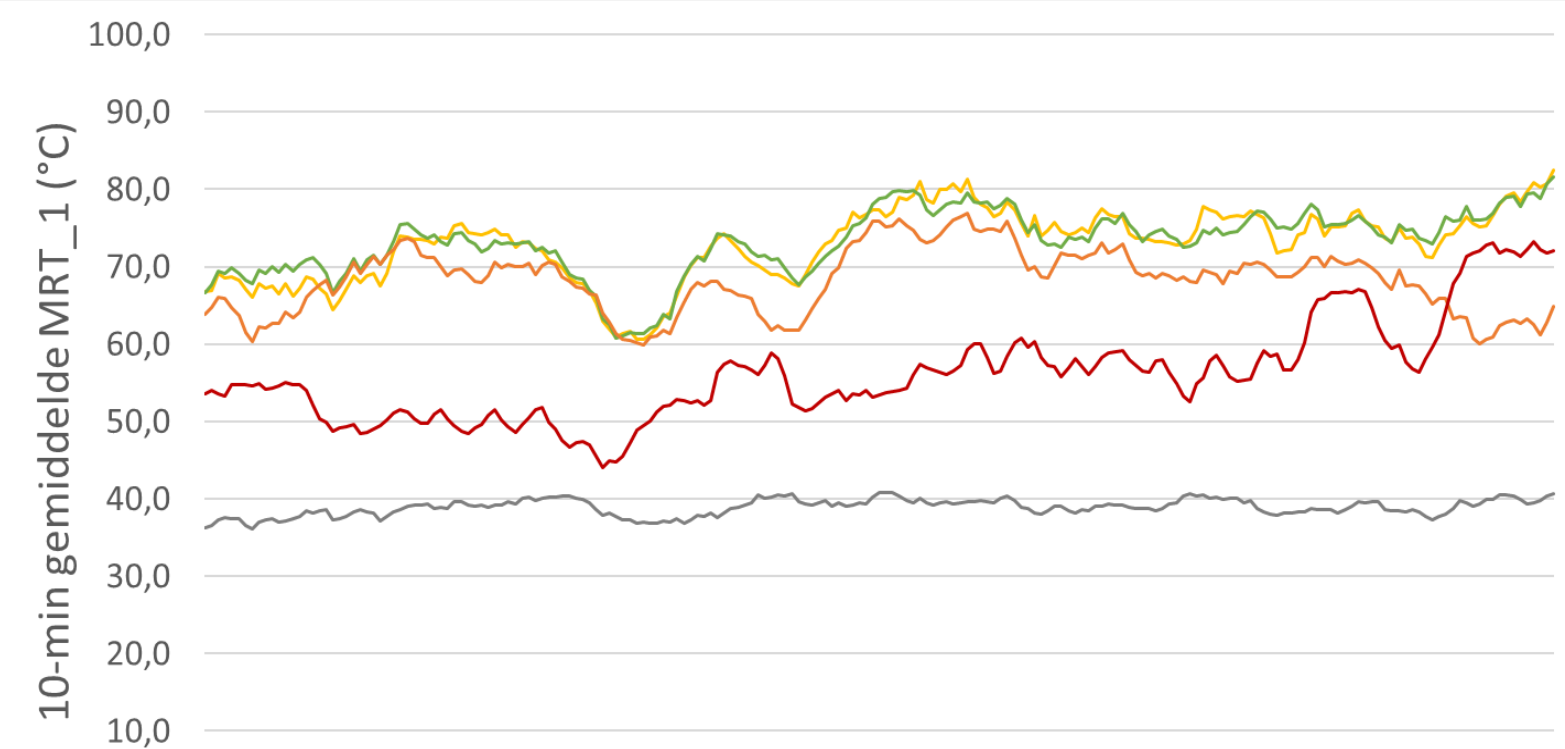

$$
0,0
$$

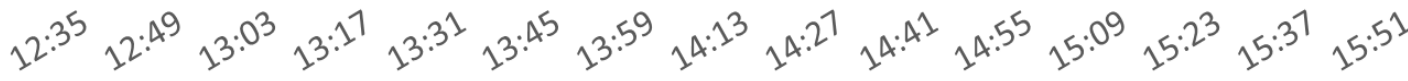

$$
\begin{aligned}
& \text {-K\#5 - K\#6 - K\#4 - К\#2 - К\#7 }
\end{aligned}
$$

K\#5: shadow + vane mount K\#6: sun + vane mount

K\#4: sun + vane mount + roof

K\#2: sun + shadow of Kestrel

K\#7: direct sun

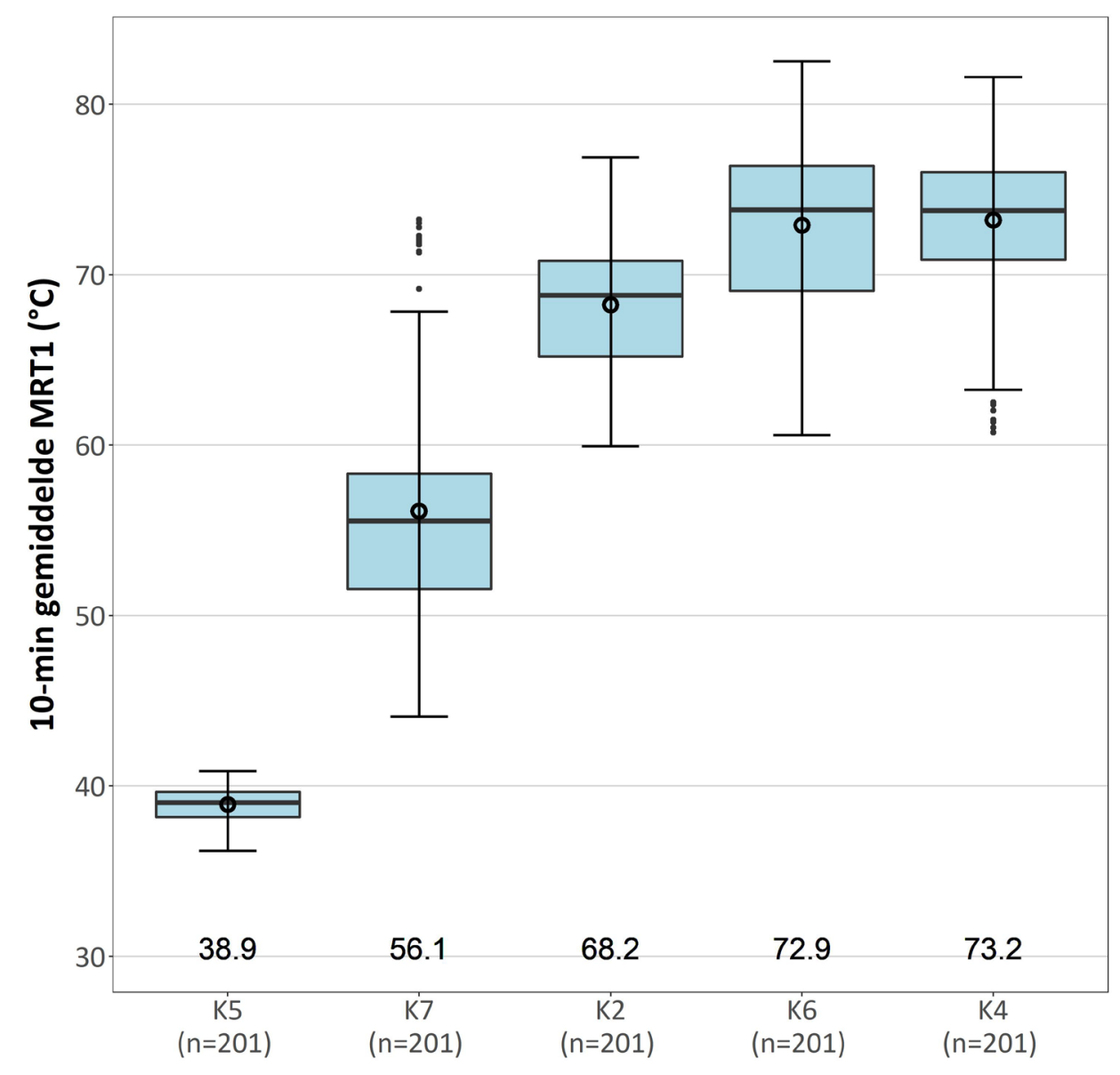




\section{Results - 10-min PET}

\section{3rd experiment: Stadionbuurt}

$$
60,0
$$

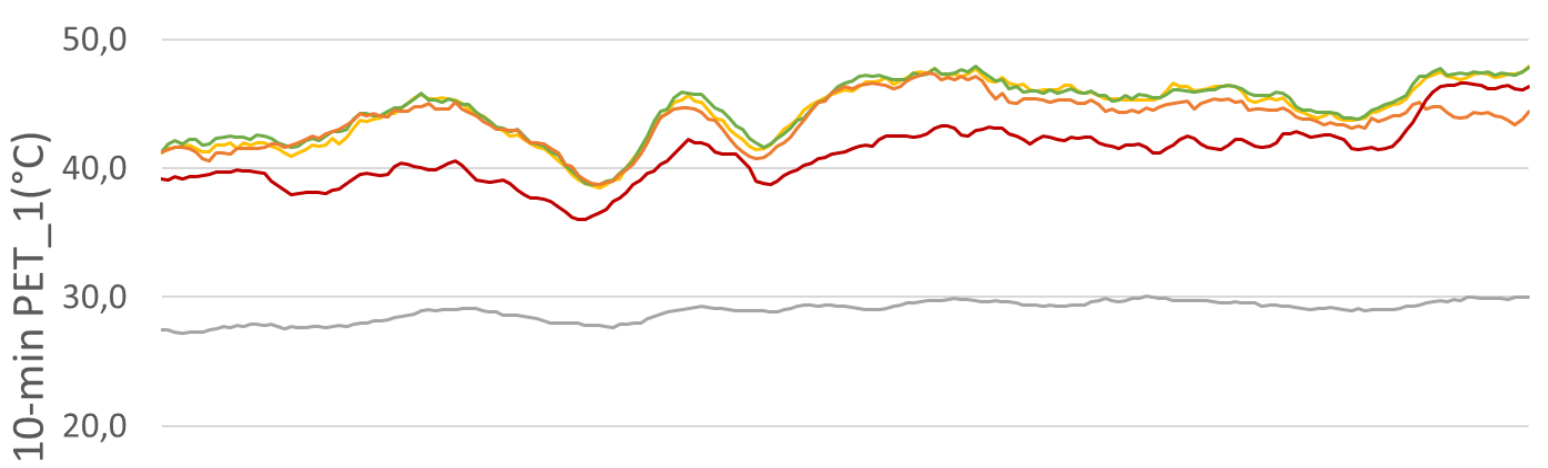

10,0

$$
\begin{aligned}
& 0,0
\end{aligned}
$$

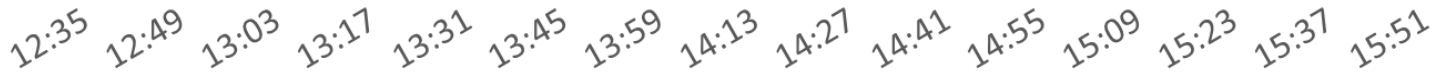

$$
\begin{aligned}
& \text {-K\#5 - К\#6 - К\#4 -K\#2 - К\#7 }
\end{aligned}
$$

\section{K\#5: shadow + vane mount} K\#6: sun + vane mount

K\#4: sun + vane mount + roof K\#2: shadow of Kestrel

K\#7: direct sun

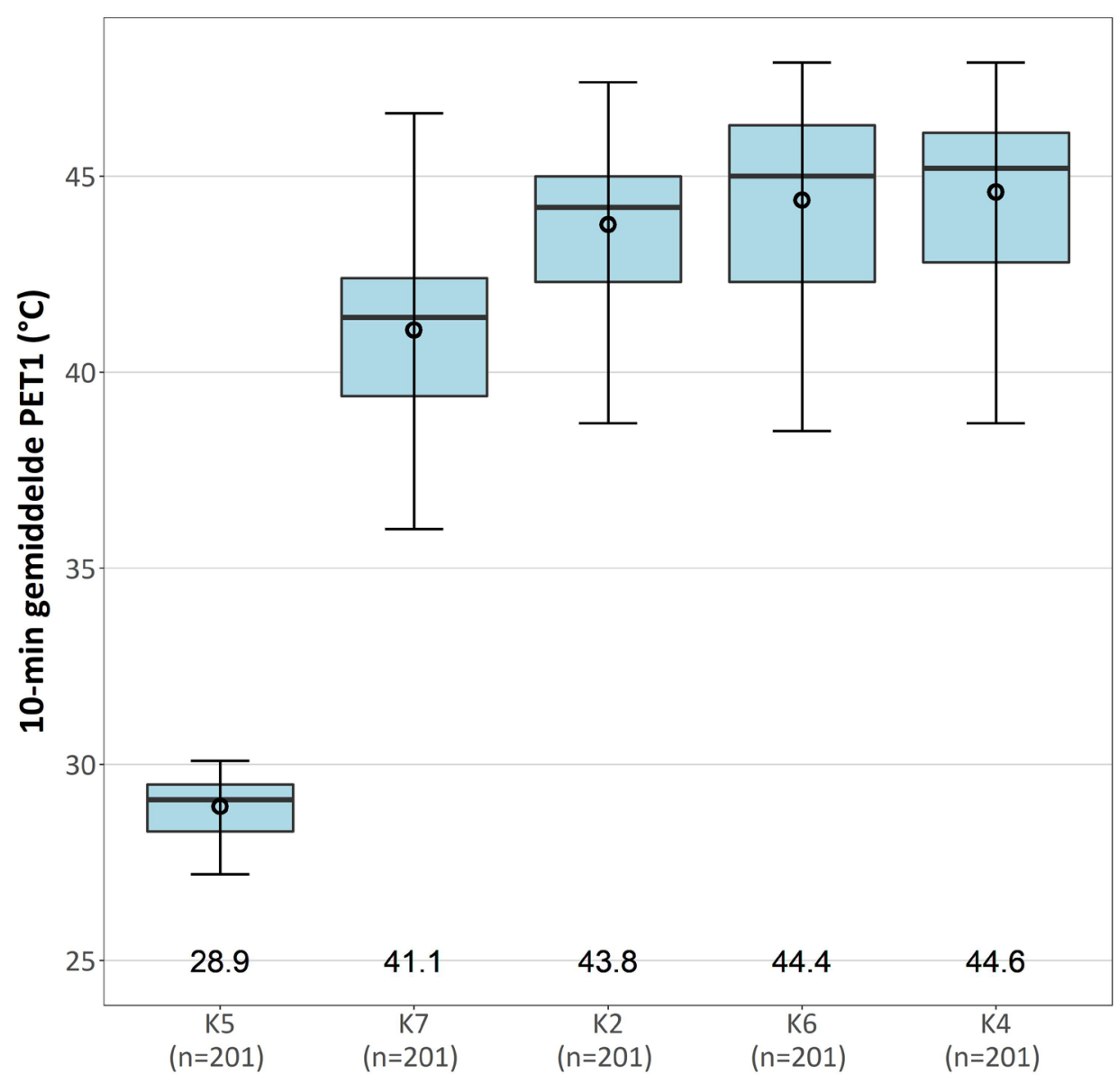




\section{Results}

\section{Average results \pm standard deviation}

\begin{tabular}{|c|c|c|c|c|c|}
\hline & K\#5 & K\#6 & K\#4 & K\#7 & K\#2 \\
\hline Luchttemperatuur $\left({ }^{\circ} \mathrm{C}\right)$ & $27,5 \pm 0,6$ & $28,2 \pm 0,9$ & $28,2 \pm 0,8$ & $31,6 \pm 1,5$ & $28,6 \pm 1,2$ \\
\hline Luchtvochtigheid (\%) & $37,3 \pm 1,6$ & $36,2 \pm 1,6$ & $36,4 \pm 1,7$ & $30,7 \pm 2,7$ & $35,6 \pm 1,9$ \\
\hline Windsnelheid $(\mathrm{m} / \mathrm{s})$ & $2,1 \pm 1,0$ & $2,0 \pm 0,9$ & $1,9 \pm 0,8$ & $1,3 \pm 0,9$ & $1,5 \pm 0,7$ \\
\hline Globe temperatuur $\left({ }^{\circ} \mathrm{C}\right)$ & $30,2 \pm 0,6$ & $40,8 \pm 1,8$ & $41,0 \pm 1,8$ & $39,3 \pm 1,9$ & $40,8 \pm 1,7$ \\
\hline $\left.\operatorname{MnT1}(5 \mathrm{~min}){ }^{\prime 0} \mathrm{C}\right)$ & $30,0 \leq 1,0$ & $72,0 \leq 5,0$ & $73,2 \leq 5,4$ & $50,1 \pm 0,0$ & $60,0 \leq 5,1$ \\
\hline MRT1 $(10 \mathrm{~min})\left({ }^{\circ} \mathrm{C}\right)$ & $38,9 \pm 1,1$ & $72,9 \pm 4,7$ & $73,2 \pm 4,2$ & $56,1 \pm 6,5$ & $68,2 \pm 4,2$ \\
\hline ivintz (Jminitiol & $30,3 \pm 1,0$ & $74,4 \pm 0,0$ & $74,0 \pm 5,5$ & $64,1 \pm 7,5$ & $70,1 \pm 5,2$ \\
\hline innT2 $(10 \mathrm{~min}) 1^{\circ} \mathrm{C}$ & 30,0 & 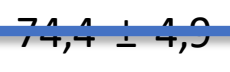 & 74,7 & $64,0 \leq 6,2$ & $70,3 \leq 4,0$ \\
\hline ncT1 (c min) / (이) & $20,0 \pm 0,0$ & $11,1 \pm 2,6$ & $11,6 \pm 2,5$ & $11,1 \pm 2,6$ & $13,7 \pm 2,1$ \\
\hline $\operatorname{PET} 1(10 \mathrm{~min})\left({ }^{\circ} \mathrm{C}\right)$ & $28,9 \pm 0,8$ & $44,4 \pm 2,3$ & $44,6 \pm 2,2$ & $41,1 \pm 2,3$ & $43,8 \pm 1,9$ \\
\hline PcT2 (c mini $\left.)^{\circ} \mathrm{C}\right)$ & $20,0 \leq 0,0$ & $44,5 \leq 2,6$ & $44,7 \pm 2,5$ & $11,1,1 \leq 2,7$ & $43,0 \leq 2,2$ \\
\hline PrT2 $(10 \mathrm{~min}))^{\circ}$ & 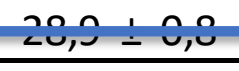 & $44,5 \leq 2$ & $44,7 \pm 2,2$ & 191,7 & 4 \\
\hline
\end{tabular}

\footnotetext{
K\#5: shadow + vane mount K\#6: sun + vane mount

K\#4: sun + vane mount + roof K\#2: sun + shadow of Kestrel K\#7: direct sun
} 


\section{Conclusions based on experiment 3}

- A Kestrel in direct sunlight can measure an air temperature that's $4,1^{\circ} \mathrm{C}$ higher than when it's placed in the shadow.

- $\quad$ But when the vane mount is mounted on the Kestrel and the Kestrel can rotate freely, this difference decreases to $0,8{ }^{\circ} \mathrm{C}$. By using the vane mount, the air temperature sensor on the Kestrel is always directed in the wind direction causing the sensor not to heat. Because of that placing a vane mount is the most important tip when preforming accurate temperature measurements with a Kestrel in direct sunlight.

- Mounting an extra paper roof on top of the radiation screen does not make a difference in measured air temperature.

- As was concluded in the experiment on the Stadionplein (experiment 2), Kestrel also measures a lower globe temperature when it is placed in direct sun without a wind vane. Therefore, a Kestrel in direct sunlight without a wind vane is not suited for estimating the MRT.

- Even though the Kestrel sensors do measure air temperatures and globe temperatures correctly in sunlight, the influence of this on the calculation of PET is minimal, being $0,6^{\circ} \mathrm{C}$. This is caused by the higher air temperatures measured by the Kestrels that are compensated by the lower MRT values. 


\section{CONCLUSIONS}

We concluded that Kestrel sensors can be used very well for assessing differences in air temperature and PET (Physiological Equivalent Temperature) between outdoor built environments. For both air temperature and PET, the RMSE between the 11 Kestrel sensors was $0.5^{\circ} \mathrm{C}$ maximum when measuring the same conditions.

However, Kestrel sensors that were placed in the sun without a wind vane mounted to the equipment showed large radiation errors. In this case, temperature differences up to $4{ }^{\circ} \mathrm{C}$ were observed compared to Kestrels that were shaded. The effect of a higher air temperature on the PET calculation is, however, surprisingly small. A sensitivity analysis showed that an increase of $3^{\circ} \mathrm{C}$ in the air temperature results in a maximal PET reduction of $0.5^{\circ} \mathrm{C}$.

We concluded that Kestrel sensors can very well be used for assessing differences between air temperatures and PET between two locations and assessing the thermal effects of urban designs, but care should be taken when air temperature measurements are carried out in the sun.

We always recommend using the wind vanes to deviate from high radiant input orientations for the temperature sensor. Always place the stations next to each other at the beginning and at the end of the measurements to check whether the stations actually measure the same values. Any differences can be corrected afterwards. 